\title{
Climate impacts on vegetation and fire dynamics since the last deglaciation at Moossee (Switzerland)
}

\author{
Fabian Rey ${ }^{1,2,3}$, Erika Gobet ${ }^{1,2}$, Christoph Schwörer ${ }^{1,2}$, Albert Hafner ${ }^{2,4}$, Sönke Szidat ${ }^{2,5}$, and Willy Tinner ${ }^{1,2}$ \\ ${ }^{1}$ Institute of Plant Sciences, University of Bern, 3013 Bern, Switzerland \\ ${ }^{2}$ Oeschger Centre for Climate Change Research, University of Bern, 3012 Bern, Switzerland \\ ${ }^{3}$ Geoecology, Department of Environmental Sciences, University of Basel, 4056 Basel, Switzerland \\ ${ }^{4}$ Institute of Archaeological Sciences, University of Bern, 3012 Bern, Switzerland \\ ${ }^{5}$ Department of Chemistry and Biochemistry, University of Bern, 3012 Bern, Switzerland
}

Correspondence: Fabian Rey (fabian.rey@unibas.ch)

Received: 22 September 2019 - Discussion started: 7 October 2019

Revised: 2 July 2020 - Accepted: 3 July 2020 - Published: 28 July 2020

\begin{abstract}
Since the Last Glacial Maximum (LGM; end ca. 19000 cal BP) central European plant communities have been shaped by changing climatic and anthropogenic disturbances. Understanding long-term ecosystem reorganizations in response to past environmental changes is crucial to draw conclusions about the impact of future climate change. So far, it has been difficult to address the post-deglaciation timing and ecosystem dynamics due to a lack of well-dated and continuous sediment sequences covering the entire period after the LGM. Here, we present a new paleoecological study with exceptional chronological time control using pollen, spores and microscopic charcoal from Moossee (Swiss Plateau, $521 \mathrm{~m}$ a.s.l.) to reconstruct the vegetation and fire history over the last ca. 19000 years. After lake formation in response to deglaciation, five major pollen-inferred ecosystem rearrangements occurred at ca. $18800 \mathrm{cal} \mathrm{BP}$ (establishment of steppe tundra), $16000 \mathrm{calBP}$ (spread of shrub tundra), 14600 cal BP (expansion of boreal forests), $11600 \mathrm{cal}$ BP (establishment of the first temperate deciduous tree stands composed of, e.g., Quercus, Ulmus, Al$n u s$ ) and $8200 \mathrm{cal} \mathrm{BP}$ (first occurrence of mesophilous $\mathrm{Fa}$ gus sylvatica trees). These vegetation shifts were caused by climate changes at ca. 19000,16000,14700, 11700 and $8200 \mathrm{cal}$ BP. Vegetation responses occurred with no apparent time lag to climate change when the mutual chronological uncertainties are considered. This finding is in agreement with further evidence from southern and central Europe and might be explained by the proximity to the refugia of boreal and temperate trees $(<400 \mathrm{~km})$ and rapid
\end{abstract}

species spreads. Our palynological record sets the beginning of millennial-scale land use with periodically increased fire and agricultural activities of the Neolithic period at ca. 7000 cal BP. Subsequently, humans rather than climate triggered changes in vegetation composition and structure. We conclude that Fagus sylvatica forests were resilient to long-term anthropogenic and climatic impacts of the Mid and the Late Holocene. However, future climate warming and in particular declining moisture availability may cause unprecedented reorganizations of central European beech-dominated forest ecosystems.

\section{Introduction}

In the near term, rapid climatic and environmental changes hold a substantial risk to modify irreversibly plant ecosystems in Europe (Schumacher and Bugmann, 2006; Kovats et al., 2014; Bugmann et al., 2015). Quantifying the response or resilience of ecosystems to environmental change in the past largely improves our capacity to assess future impacts of climate and global change (Henne et al., 2015). Specifically, paleoecological data offer the great opportunity to study long-term climate-vegetation interactions under conditions that exceed the variability and duration recorded in historical archives or through measurements and experiments (Willis and Birks, 2006; Birks et al., 2016b; Henne et al., 2018). 
During the Last Glacial Maximum (LGM), large areas in central and southern Europe around the Alps, in the Jura Mountains, the Black Forest, the Vosges and the Apennines were covered by ice (Ehlers and Gibbard, 2004; Bini et al., 2009; Ehlers et al., 2011; Seguinot et al., 2018). The subsequent deglaciation is generally well-studied; however, timing issues remain due to dating uncertainties (e.g., Wirsig et al., 2016). Recent advances in accelerator mass spectrometry (AMS) radiocarbon dating offer the possibility to produce reliable results with relatively small chronological uncertainties when using samples with extremely low carbon contents (Szidat et al., 2014; Uglietti et al., 2016). Radiocarbon dates on terrestrial plant remains extracted from the very bottom of lake sediments from sites close to the LGM glacier margins may thus help to refine the onset of deglaciation. However, only very few sedimentary records providing reliable deglaciation ages (i.e., no bulk dating, only terrestrial macrofossils; Finsinger et al., 2019) are available so far from the peri-Alpine belt (e.g., Lister, 1988; Larocque and Finsinger, 2008; Lauterbach et al., 2012). Similarly, well-dated pollen profiles from western and central Europe covering the first 2 millennia of the Oldest Dryas (ca. 19000-17000 cal BP) are almost absent, and the existing chronologies are therefore often inadequate (e.g., Woillard, 1978; Welten, 1982; Ammann and Tobolski, 1983; de Beaulieu and Reille, 1984; de Beaulieu and Reille, 1992). Conversely, the temporal evolution of the vegetation after $17000 \mathrm{cal} \mathrm{BP}$ is better known (e.g., Lotter, 1999; Tinner et al., 1999; Duprat-Oualid et al., 2017; Rey et al., 2017). Various sites south of the Alps indicate a first afforestation at ca. 16000 cal BP (e.g., Vescovi et al., 2007), and the main cause has been identified as the post-Heinrich event (HE) 1 warming (Samartin et al., 2012). At around $16000 \mathrm{cal}$ BP shrub and probably even tree birches expanded into the steppe tundra north of the Alps (Lotter, 1999; Duprat-Oualid et al., 2017; Rey et al., 2017), forming open parklands or shrub tundra. North of the Alps, forests expanded after $14700 \mathrm{calBP}$ as a consequence of the Bølling warming (Ammann et al., 2013; van Raden et al., 2013), a process which was delayed by almost 1500 years compared to the lowlands south of the Alps (Vescovi et al., 2007). The reasons causing this long time lag are not yet fully understood, but it might be related to a strong latitudinal temperature gradient and the presence of large Arctic ice masses (Heiri et al., 2014). The subsequent forested Late Glacial and Holocene vegetation history of the Swiss Plateau is best-studied and the chronological framework is quite robust (e.g., Lotter, 1999; Wehrli et al., 2007; Rey et al., 2017).

Taken together, despite the long tradition of paleoecological research in central Europe with quite a high density of well-dated and highly resolved studies, a profound modern assessment of the major vegetation changes and their main causes is currently lacking for the complete post-LGM time period. Here, the novel Moossee record has the great potential to shed new light on the timing of lake formation and on important vegetation reorganizations for the past 19000 years in a central area of the Swiss Plateau. In this study we aim (1) to reconstruct the timing of deglaciation and the establishment of the first pioneer vegetation around the lake after the LGM, (2) to identify major postglacial changes in ecosystem evolution on the Swiss Plateau and to assess their causes, (3) to discuss the resilience and the vulnerability of central European lowland forests in the past to inform the near future and (4) to emphasize the utility of exceptional temporal precision and resolution.

\section{Study site}

Moossee is a small eutrophic lake at $512 \mathrm{~m}$ a.s.l. $\left(47^{\circ} 1^{\prime} 17.0^{\prime \prime} \mathrm{N}, 7^{\circ} 29^{\prime} 1.7^{\prime \prime} \mathrm{E}\right)$ located on the Swiss Plateau within the periphery of the Swiss capital Bern. Geologically, the study area belongs to the carbonate-rich molasse region with predominantly sandstone in between the Jura Mountains in the north and the Alps in the south (Schmid et al., 2004). The lake formed after the retreat of the Rhône glacier after the LGM and has a surface area of $0.31 \mathrm{~km}^{2}$, with one main inflow in the west and one outflow in the east (Fig. 1b). The maximum water depth is $22 \mathrm{~m}$, with generally anoxic waters in the hypolimnion below $12 \mathrm{~m}$ (Guthruf et al., 1999). The lake used to be at least 10 times larger in the past, but its size has shrunk due to peat formation over the millennia and artificial lake level lowering (by 4-5 m) since the late 18th century. Lake levels were lowered to drain the wetlands for peat exploitation and to gain agricultural land (von Büren, 1943; Guthruf et al., 1999; Harb, 2017; Fig. 1b). The climate at Moossee is oceanic with mean annual temperatures of $8.8^{\circ} \mathrm{C}$ and an annual rainfall of $1059 \mathrm{~mm}$ (data from Bern-Zollikofen at ca. $3 \mathrm{~km}$ distance; MeteoSwiss, 2017). July is the warmest month with a mean temperature of $18.6^{\circ} \mathrm{C}$. The wettest months are May-August with more than $100 \mathrm{~mm}$ of rainfall per month (MeteoSwiss, 2017).

Alnus glutinosa and Fraxinus excelsior form fragmented stands along the lake shore, whereas mixed Fagus sylvatica forests are dominant on the more elevated surrounding hills. The remaining and rather flat areas are either intensively used for agriculture or covered by settlements and infrastructure. The earliest archeological findings around the lake date back to the Magdalenien and the Upper Paleolithic: ca. $15950-14750 \mathrm{cal}$ BP (14000-12 $800 \mathrm{cal} \mathrm{BCE})$. At that time, two reindeer hunter camps (Moosbühl I and II) were located at the former lake shore (Bullinger et al., 1997; Harb, 2017; Nielsen, 2018; Fig. 1b). Many finds, including preserved lake-shore villages, are known from the Neolithic from ca. $6450 \mathrm{calBP}$ on $(4500 \mathrm{cal} \mathrm{BCE})$, impressively documenting the strong prehistoric human activities in the region (Hafner et al., 2012; Harb, 2017; Fig. 1b). The following Bronze Age and early Iron Age is represented with scattered artifacts and grave mounds in the 

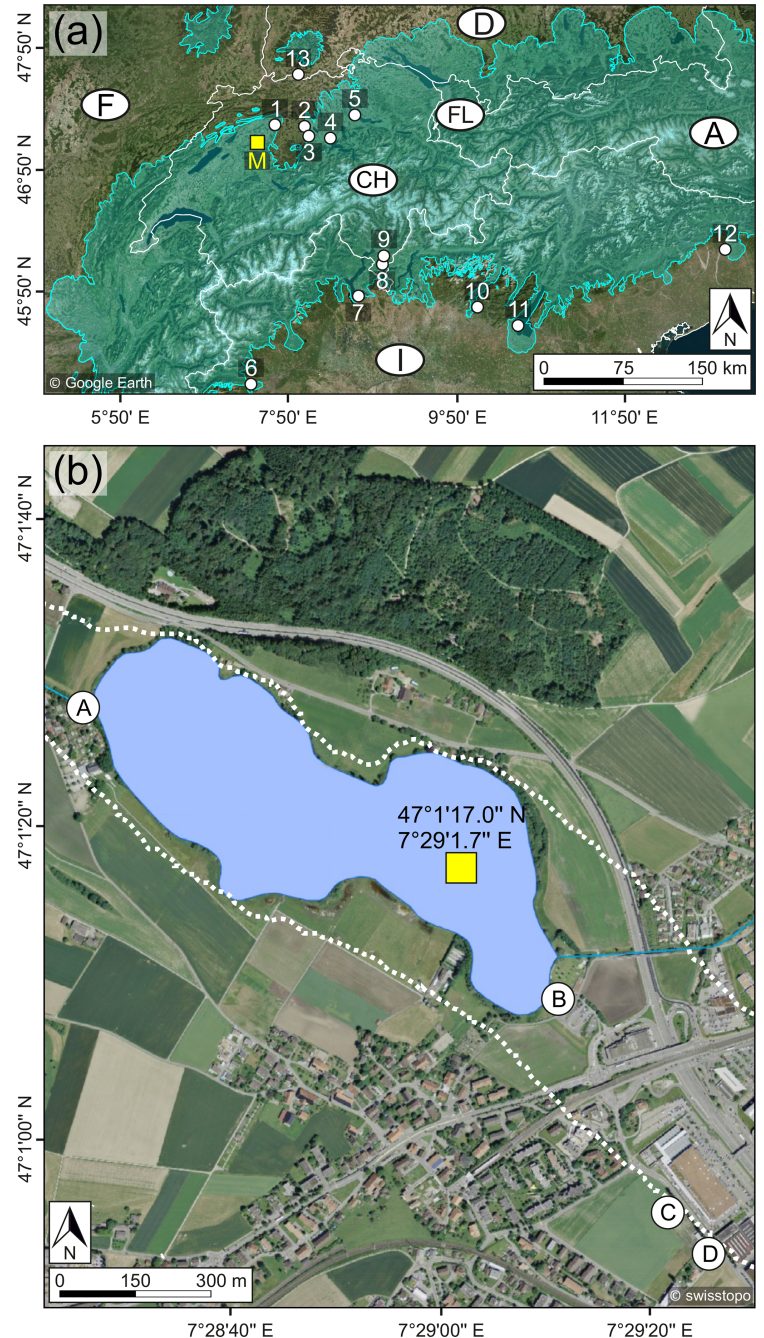

Figure 1. (a) Overview map of Switzerland $(\mathrm{CH})$ and the neighboring countries (white lines: national borders; source of the satellite image: Google Earth (modified)) including the glacier extent during the Last Glacial Maximum (LGM, turquoise area; Ehlers and Gibbard, 2004), the study site Moossee (M, yellow box) and other discussed sites (white circles). 1: Burgäschisee (Rey et al., 2017); 2: Wauwilermoos (Beckmann, 2004); 3: Soppensee (Lotter, 1999); 4: Rotsee (Lotter and Zbinden, 1989); 5: Lake Zürich (Lister, 1988); 6: Lago Piccolo di Avigliana (Larocque and Finsinger, 2008); 7: Lago di Monate (this work); 8: Lago di Origlio (Tinner et al., 1999); 9: Gola di Lago (this work); 10: Lago d'Iseo (Lauterbach et al., 2012); 11: Lago di Garda (Ravazzi et al., 2014); 12: Lago di Ragogna (Monegato et al., 2007); 13: Bergsee (Duprat-Oualid et al., 2017). A: Austria; D: Germany; F: France; FL: Liechtenstein; I: Italy. (b) Detailed map of Moossee (blue area: present lake surface area; source of the aerial photograph: swisstopo (modified)), the extent of the former lake area (dotted white line; Harb, 2017), the coring coordinates (yellow box) and local archeological sites (white circles; Harb, 2017). A: Moossee West; B: Moossee East; C: Moosbühl II; D: Moosbühl I. proximity of the lake (Harb, 2017). In the Bern area the first urban center was the oppidum Brenodor, which was built during the late Iron Age or La Tène period (Ebnöther and Wyss, 2004). It persisted during the Roman Age as the vicus Brenodurum. The Iron Age and Roman ruins (e.g., fortifications, bath, amphitheater) are still visible in the town on the Enge peninsula at $5 \mathrm{~km}$ distance from Moossee (Ebnöther and Wyss, 2004). Finally, the medieval city center, which is part of the UNESCO World Heritage "Old City of Bern", was founded in $1191 \mathrm{CE}$ around the Nydegg castle that already existed before (Hofer and Meyer, 1991).

\section{Materials and methods}

\subsection{Coring and chronology}

Six parallel sediment cores were retrieved at $19 \mathrm{~m}$ water depth with a UWITEC piston corer in the eastern part of the lake. Three cores (Moos A-C; core diameter: $60 \mathrm{~mm}$; core length: $300 \mathrm{~cm}$ ) reached coring depths of ca. $17.5 \mathrm{~m}$. For the other three cores (Moos F-H; core diameter: $90 \mathrm{~mm}$; core length: $200 \mathrm{~cm}$ ), due to higher friction it was only possible to recover the uppermost $7 \mathrm{~m}$. A master sequence with a total length of $16.44 \mathrm{~m}$ was defined using the Moos F-H cores for the uppermost $7 \mathrm{~m}$ and the Moos A-C cores for the remaining part. The sediment material below $13.5 \mathrm{~m}$ was not analyzed due to frequent sand layers in the lowermost part resulting in very low pollen concentrations.

The chronology is based on 62 radiocarbon dates on terrestrial plant macrofossils and the Laacher See Tephra (LST; Table 1). The radiocarbon content of terrestrial plant remains was measured at the LARA laboratory at the University of Bern using AMS (Szidat et al., 2014). None of the 62 radiocarbon dates was rejected. From 435 to $691 \mathrm{~cm}$, additional varve counts were applied to refine the chronology. Here, the program OxCal 4.3 (V-sequence, Bronk Ramsey, 1994, 1995, 2001; Bronk Ramsey et al., 2001) and the IntCal13 calibration curve (Reimer et al., 2013) were used to estimate the age-depth model and its $95 \%(2 \sigma)$ probabilities (partly published, Rey et al., 2019b). For the remaining part $(0-435 \mathrm{~cm}$ and $691-1335 \mathrm{~cm})$, a smooth-spline curve (smoothing level $=0.3$ ) was calculated with the program clam 2.2 (Blaauw, 2010) to assess the final age-depth model (Fig. 2). The modeled curve runs within the $95 \%(2 \sigma)$ probabilities of the calibrated radiocarbon ages and the $2 \sigma$ confidence envelope of a generalized mixedeffect regression that includes both sample depth and age uncertainties (GAM, Heegaard et al., 2005).

\subsection{Pollen, non-pollen palynomorphs and charcoal analysis}

A total of 514 samples for pollen and microscopic charcoal analyses were taken from the sediment core from $1296 \mathrm{~cm}$ to the top. The standard sampling was $1 \mathrm{~cm}^{3}$ 
Table 1. Radiocarbon dates and calibrated ages from the Moossee record. Uncertainties in ${ }^{14} \mathrm{C}$ ages refer to $68 \%$ probabilities $(1 \sigma)$, whereas ranges of calibrated and modeled ages represent $95 \%$ probabilities $(2 \sigma)$. Indet: indeterminable.

\begin{tabular}{|c|c|c|c|c|c|}
\hline Lab. code & Depth (cm) & ${ }^{14} \mathrm{C}$ age $(\mathrm{BP})^{\mathrm{a}}$ & $\begin{array}{r}\text { Age } \\
\text { range } \\
(\mathrm{cal} \mathrm{BP})^{\mathrm{b}}\end{array}$ & $\begin{array}{l}\text { Modeled } \\
\text { age range } \\
(\mathrm{cal} \mathrm{BP})^{\mathrm{c}}\end{array}$ & Material \\
\hline BE-7363.1.1 & $78.6-75.9$ & $150 \pm 20$ & $5-280$ & $-135-420$ & Picea abies needle \\
\hline BE-7362.1.2 & $104.7-102.2$ & $240 \pm 70$ & $5-480$ & $-230-700$ & Leaf indet \\
\hline BE-7361.1.1 & $187.5-186.3$ & $450 \pm 20$ & $495-525$ & $475-545$ & Leaf fragments indet \\
\hline BE-7360.1.1 & $241.6-239.8$ & $1065 \pm 20$ & $930-1050$ & $870-1110$ & Alnus glutinosa fruit \\
\hline BE-7359.1.1 & $261.1-259.9$ & $1110 \pm 35$ & $935-1170$ & $820-1285$ & Alnus glutinosa fruit \\
\hline BE-7358.1.1 & $324.4-321.1$ & $1495 \pm 40$ & $1305-1520$ & $1205-1620$ & Betula fruits, Fagus sylvatica bud scales \\
\hline BE-7357.1.1 & $328.0-325.1$ & $1535 \pm 30$ & $1360-1520$ & $1270-1600$ & $\begin{array}{l}\text { Betula fruits, Fagus sylvatica bud scales, Salix bud } \\
\text { scale, bud scale indet }\end{array}$ \\
\hline BE-7356.1.1 & $330.8-328.6$ & $1555 \pm 40$ & $1360-1535$ & $1285-1625$ & $\begin{array}{l}\text { Betula fruit, Fagus sylvatica bud scale, Populus } \\
\text { tremula floral bract }\end{array}$ \\
\hline BE-7355.1.1 & $338.5-332.2$ & $1620 \pm 40$ & $1410-1605$ & $1320-1700$ & $\begin{array}{l}\text { Betula fruits, Fagus sylvatica bud scale, Populus } \\
\text { tremula floral bract, Quercus bud scales }\end{array}$ \\
\hline BE-7354.1.1 & $346.9-339.8$ & $1700 \pm 40$ & $1535-1705$ & $1450-1785$ & Betula fruits, Populus tremula floral bract \\
\hline BE-7353.1.1 & $386.5-385.9$ & $2060 \pm 35$ & $1935-2120$ & $1840-2215$ & Terrestrial fruit indet \\
\hline BE-7352.1.1 & $416.2-409.3$ & $2290 \pm 50$ & $2150-2400$ & $2025-2525$ & Betula fruit, Betula fruits scales \\
\hline BE-7351.1.1 & $435.0-432.7$ & $2420 \pm 35$ & $2350-2700$ & $2655-2705$ & Fagus sylvatica bud scales \\
\hline BE-7350.1.1 & $439.0-438.1$ & $2630 \pm 50$ & $2540-2860$ & $2730-2775$ & Betula fruit, Betula fruit scale \\
\hline BE-7349.1.1 & $441.4-439.7$ & $2730 \pm 35$ & $2760-2920$ & $2765-2810$ & $\begin{array}{l}\text { Abies alba bud scale, Fagus sylvatica bud scales, } \\
\text { terrestrial fruit indet }\end{array}$ \\
\hline BE-7348.1.1 & $447.0-446.4$ & $2795 \pm 40$ & $2790-2990$ & $2875-2920$ & Fagus sylvatica bud scale \\
\hline BE-7347.1.1 & $449.9-448.8$ & $2810 \pm 45$ & $2790-3055$ & $2910-2960$ & Betula fruit, Fagus sylvatica bud scales \\
\hline BE-7346.1.1 & $453.0-452.5$ & $2900 \pm 45$ & $2890-3170$ & $2965-3020$ & Bud scale indet \\
\hline BE-7345.1.1 & $461.1-460.0$ & $3010 \pm 40$ & $3070-3340$ & $3085-3135$ & $\begin{array}{l}\text { Abies alba bud scale, Alnus glutinosa bud scale, } \\
\text { Betula fruits, bud scale indet, petiole indet }\end{array}$ \\
\hline BE-7344.1.1 & $468.3-466.9$ & $3010 \pm 40$ & $3070-3340$ & $3185-3240$ & $\begin{array}{l}\text { Alnus glutinosa fruit, Betula fruits, Populus tremula } \\
\text { floral bract }\end{array}$ \\
\hline BE-7343.1.1 & $472.7-472.0$ & $3070 \pm 45$ & $3165-3380$ & $3245-3300$ & Alnus glutinosa bud scale \\
\hline BE-7342.1.1 & $495.8-495.0$ & $3245 \pm 50$ & $3375-3575$ & $3490-3550$ & Leaf fragments indet \\
\hline BE-7341.1.1 & $498.0-497.3$ & $3315 \pm 40$ & $3455-3640$ & $3520-3580$ & Abies alba bud scale, Fagus sylvatica bud scale \\
\hline BE-7340.1.1 & $500.2-499.0$ & $3295 \pm 45$ & $3405-3635$ & $3555-3610$ & Fagus sylvatica bud scale, terrestrial fruit indet \\
\hline BE-7339.1.1 & $502.9-501.3$ & $3395 \pm 40$ & $3515-3820$ & $3585-3650$ & $\begin{array}{l}\text { Abies alba bud scale, Betula fruit, Fagus sylvatica } \\
\text { bud scales, Quercus bud scale, bud scale indet, } \\
\text { terrestrial fruit indet }\end{array}$ \\
\hline BE-5380.1.1 & $520.2-519.5$ & $3615 \pm 35$ & $3835-4070$ & $3840-3885$ & Alnus glutinosa fruit, terrestrial plant remain indet \\
\hline BE-5631.1.1 & $540.3-539.8$ & $3765 \pm 40$ & $3985-4245$ & $4065-4105$ & Alnus glutinosa fruit, leaf fragment indet \\
\hline BE-5381.1.1 & $543.5-543.0$ & $3710 \pm 35$ & $3930-4150$ & $4110-4145$ & Betula fruit, Fagus sylvatica bud scales \\
\hline BE-5632.1.1 & $548.4-547.7$ & $3865 \pm 40$ & $4155-4415$ & $4180-4220$ & Fagus sylvatica bud scales \\
\hline BE-5382.1.1 & $553.1-552.4$ & $3865 \pm 35$ & $4160-4415$ & $4270-4305$ & Fagus sylvatica bud scales \\
\hline BE-5383.1.1 & $569.8-569.2$ & $4190 \pm 35$ & $4590-4840$ & $4655-4685$ & Abies alba needle, Fagus sylvatica bud scale \\
\hline BE-5633.1.1 & $572.4-571.6$ & $4160 \pm 40$ & $4570-4830$ & $4695-4720$ & $\begin{array}{l}\text { Alnus glutinosa fruit, Betula fruit, Fagus sylvatica } \\
\text { bud scale }\end{array}$ \\
\hline
\end{tabular}


Table 1. Continued.

\begin{tabular}{|c|c|c|c|c|c|}
\hline Lab. code & Depth $(\mathrm{cm})$ & ${ }^{14} \mathrm{C}$ age $(\mathrm{BP}){ }^{\mathrm{a}}$ & $\begin{array}{r}\text { Age } \\
\text { range } \\
(\mathrm{cal} \mathrm{BP})^{\mathrm{b}}\end{array}$ & $\begin{array}{r}\text { Modeled } \\
\text { age range } \\
(\text { cal BP })^{\mathrm{c}}\end{array}$ & Material \\
\hline BE-5384.1.1 & $578.7-578.3$ & $4250 \pm 20$ & $4825-4855$ & $4835-4860$ & $\begin{array}{l}\text { Populus tremula floral bract, leaf fragments } \\
\text { indet }\end{array}$ \\
\hline BE-5385.1.1 & $604.6-604.0$ & $4730 \pm 20$ & $5330-5580$ & $5330-5360$ & $\begin{array}{l}\text { Alnus glutinosa bud scale, Alnus glutinosa } \\
\text { catkin, Betula fruits }\end{array}$ \\
\hline BE-5634.1.1 & $606.3-605.8$ & $4740 \pm 40$ & $5325-5585$ & $5355-5385$ & Alnus glutinosa bud scale, Alnus glutinosa fruit \\
\hline BE-5635.1.1 & $607.7-607.2$ & $4690 \pm 45$ & $5315-5580$ & $5395-5420$ & Alnus glutinosa bud scale, Betula fruit \\
\hline BE-5636.1.1 & $612.0-611.5$ & $4830 \pm 70$ & $5330-5720$ & $5500-5530$ & Betula fruits, Fagus sylvatica bud scale \\
\hline BE-5386.1.1 & $618.7-618.1$ & $4970 \pm 25$ & $5615-5745$ & $5640-5675$ & $\begin{array}{l}\text { Abies alba seed, Fagus sylvatica bud scale, } \\
\text { leaf fragments indet }\end{array}$ \\
\hline BE-5387.1.1 & $624.2-623.6$ & $5035 \pm 40$ & $5660-5900$ & $5720-5755$ & $\begin{array}{l}\text { Abies alba needle, Abies alba bud scale, } \\
\text { petioles indet }\end{array}$ \\
\hline BE-5388.1.1 & $625.9-625.2$ & $5060 \pm 35$ & $5730-5905$ & $5755-5790$ & $\begin{array}{l}\text { Alnus glutinosa bud scale, Betula fruit, Fagus } \\
\text { sylvatica bud scale, leaf fragments indet }\end{array}$ \\
\hline BE-5637.1.1 & $630.8-630.3$ & $5005 \pm 50$ & $5620-5895$ & $5850-5885$ & Betula fruit, Fagus sylvatica bud scale \\
\hline BE-5389.1.1 & $636.2-635.5$ & $5235 \pm 40$ & $5915-6175$ & $5965-6005$ & Petiole indet \\
\hline BE-5638.1.1 & $641.3-640.8$ & $5375 \pm 40$ & $6005-6280$ & $6105-6140$ & Alnus glutinosa bud scale \\
\hline BE-5390.1.1 & $646.2-645.5$ & $5370 \pm 60$ & $6000-6285$ & $6230-6270$ & Fagus sylvatica bud scale \\
\hline BE-5639.1.1 & $652.7-652.1$ & $5660 \pm 45$ & $6315-6550$ & $6380-6420$ & Fagus sylvatica bud scales \\
\hline BE-5391.1.1 & $656.2-655.8$ & $5655 \pm 25$ & $6355-6495$ & $6430-6475$ & $\begin{array}{l}\text { Fagus sylvatica bud scale, bud scale indet, } \\
\text { petioles indet }\end{array}$ \\
\hline BE-5392.1.1 & $659.8-659.3$ & $5760 \pm 25$ & $6490-6635$ & $6495-6535$ & Alnus glutinosa catkin, Alnus glutinosa fruits \\
\hline BE-5640.1.1 & $669.1-668.6$ & $5875 \pm 45$ & $6565-6795$ & $6625-6670$ & Fagus sylvatica bud scale \\
\hline BE-5393.1.1 & $675.7-675.2$ & $5940 \pm 25$ & $6680-6845$ & $6740-6790$ & Fagus sylvatica bud scales, bud scales indet \\
\hline BE-5394.1.1 & $678.3-677.8$ & $5990 \pm 40$ & $6735-6940$ & $6790-6845$ & Fagus sylvatica bud scale, leaf fragments indet \\
\hline BE-5641.1.1 & $689.8-689.4$ & $6135 \pm 45$ & $6910-7160$ & $7010-7065$ & Fagus sylvatica bud scale, petiole indet \\
\hline BE-5642.1.1 & $691.2-690.8$ & $6210 \pm 45$ & $6995-7250$ & $7035-7095$ & Alnus glutinosa fruit, Tilia anthers \\
\hline BE-5395.1.1 & $767.0-765.0$ & $7850 \pm 110$ & $8440-8990$ & $8160-9270$ & Terrestrial fruit indet \\
\hline BE-5396.1.1 & $798.0-796.0$ & $8165 \pm 25$ & $9015-9245$ & $8890-9370$ & Tilia fruit scale \\
\hline BE-5397.1.1 & $867.0-865.0$ & $9380 \pm 30$ & $10520-10690$ & $10440-10805$ & $\begin{array}{l}\text { Pinus sylvestris bud scale, Populus tremula } \\
\text { floral bract, Populus tremula fruits, } \\
\text { Quercus bud scale, Ulmus bud scale }\end{array}$ \\
\hline \multirow[t]{2}{*}{ BE-5398.1.1 } & $883.0-881.0$ & $9980 \pm 60$ & $11250-11710$ & $10960-11890$ & $\begin{array}{l}\text { Betula fruits, Betula fruit scales, } \\
\text { Pinus sylvestris bud scales }\end{array}$ \\
\hline & $933.0-932.0$ & & $12885-13185^{\mathrm{d}}$ & $12740-13350$ & Laacher See Tephra (LST) \\
\hline BE-5399.1.1 & $949.0-947.0$ & $11675 \pm 35$ & $13440-13570$ & $13360-13650$ & $\begin{array}{l}\text { Betula fruits, Betula fruit scale, } \\
\text { Juniperus needles }\end{array}$ \\
\hline BE-5400.1.1 & $967.0-965.0$ & $12200 \pm 70$ & $13810-14350$ & $13520-14600$ & Betula fruits, Betula fruit scale \\
\hline BE-5401.1.1 & $983.0-981.0$ & $12350 \pm 80$ & $14070-14830$ & $13700-15210$ & Betula fruits \\
\hline BE-5402.1.1 & $1010.0-1008.0$ & $12720 \pm 170$ & $14310-15680$ & $13650-16360$ & Betula nana leaf \\
\hline BE-5403.1.1 & $1110.0-1105.0$ & $14000 \pm 210$ & $16340-17560$ & $15740-18160$ & $\begin{array}{l}\text { Betula nana fruit, Betula nana fruit scale, } \\
\text { Betula nana leaf }\end{array}$ \\
\hline BE-5404.1.1 & $1340.0-1335.0$ & $15900 \pm 130$ & $18890-19520$ & $18560-19850$ & Salix herbacea leaf, rhizome indet \\
\hline
\end{tabular}




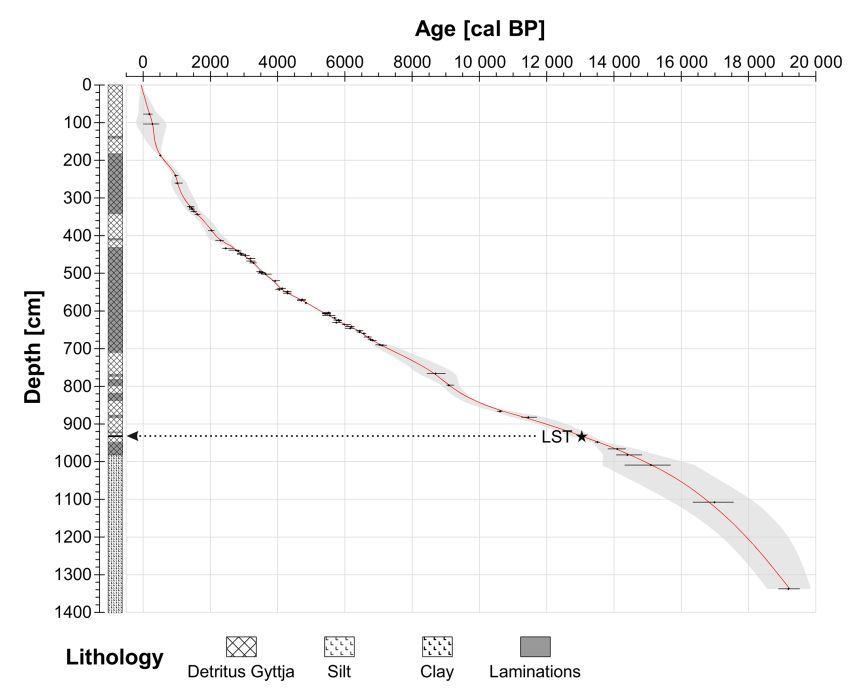

Figure 2. Age-depth model and lithology of Moossee. Black dots show the calibrated ages with $95 \%(2 \sigma)$ probabilities (IntCal13; Reimer et al., 2013). The red line is the modeled chronology using OxCal 4.3 from 435 to $691 \mathrm{~cm}$ (V-sequence; Bronk Ramsey 1994, 1995, 2001; Bronk Ramsey et al., 2001) and clam 2.2 smooth spline at smoothing level 0.3 from 0 to $435 \mathrm{~cm}$ and from 691 to $1335 \mathrm{~cm}$ (Blaauw, 2010). The $95 \%(2 \sigma)$ probabilities of the model (grey area) were calculated again using OxCal V-sequence $(435-691 \mathrm{~cm})$ and a generalized mixed-effect regression (GAM; $0-435 \mathrm{~cm}$ and 691-1335 cm; Heegaard et al., 2005). LST: Laacher See Tephra (black line at 932-933 cm and black star).

every $10 \mathrm{~cm}$. A higher resolution was implemented for the Oldest Dryas (18 800-14700 cal BP), for the Early Bølling (14700-14400) and for the Neolithic-Mid Bronze Age (7400-3200 cal BP; Rey et al., 2019a). All palynological samples were treated with $\mathrm{HCl}, \mathrm{KOH}, \mathrm{HF}$, and acetolysis and sieved with a mesh size of $0.5 \mathrm{~mm}$ and mounted in glycerine following standard approaches (Moore et al., 1991). Lycopodium tablets (University of Lund batch no. 1031 with $20848 \pm 3457$ spores per tablet) were added before the chemical treatment to estimate microfossil concentrations (Stockmarr, 1971). Pollen, spores and nonpollen palynomorphs (NPPs) were identified under a light microscope at $400 \times$ magnification using palynological keys (Moore et al., 1991; Beug, 2004), photo atlases (Reille, 1992) and the reference collection at the Institute of Plant Sciences (University of Bern). Betula nana and tree Betula pollen grains were separated following Birks (1968) and Clegg et al. (2005). Cerealia-type pollen was identified according to size, pore diameter and annulus thickness (Beug, 2004).

Pollen and spores were used to infer extra-local to regional vegetation dynamics (Conedera et al., 2006). A minimum pollen sum of 500 terrestrial pollen grains per sample was counted. For the lowest part of the sediment core, the minimum pollen sum was $>100$ terrestrial pollen grains due to the low pollen concentration in the bottom part of the sediment sequence. A total number of 165 terrestrial pollen types were identified. Sporormiella and Cercophora (coprophilous fungal spores; e.g., van Geel et al., 2003) was used as a proxy for grazing activities of herbivores (e.g., Gill et al., 2013; Rey et al., 2017) and livestock farming (e.g., Rey et al., 2013; Schwörer et al., 2015). The pollen and NPP results are presented in percentages of the terrestrial pollen sum excluding Cannabis sativa pollen (due to artificial pollen input by hemp retting; Ranalli and Venturi, 2004) and pollen of aquatic plants (Fig. 3). For Sporormiella and Cercophora, influx values (spores per square centimeter per year) are also shown (Fig. 4).

We used microscopic charcoal as a proxy for regional fire activity (Tinner et al., 1998; Adolf et al., 2018). Particles $>10$ and $<500 \mu \mathrm{m}$ were analyzed and counted on the pollen slides following Tinner and $\mathrm{Hu}$ (2003) and Finsinger and Tinner (2005). The data are presented as microscopic charcoal influx values (particles per square centimeter per year; Fig. 3). Local pollen assemblage zones (LPAZs) were identified using optimal sum-of-squares partitioning (Birks and Gordon, 1985), while statistically significant zones were determined following the broken-stick method (Bennett, 1996). For simplification and comparison with the LPAZ, we added important climatic breaks (1-5) that are either related to temperature changes (breaks 1-4; see compilation of chironomid-based July air temperature estimate since the LGM in Finsinger et al., 2019, or increases in moisture availability, e.g., Tinner and Lotter, 2001; Joannin et al., 2013). The evidence for the temperature and moisture breaks comes from previous studies: break 1 corresponds to the onset of the Oldest Dryas (19000 cal BP; e.g., Wirsig et al., 2016); break 2 to the post-HE-1 warming $(16000 \mathrm{cal} \mathrm{BP}$; e.g., Samartin et al., 2012); break 3 to the onset of the Bølling (14 700 cal BP; e.g., van Raden et al., 2013); break 4 to the onset of the Holocene (11 700 cal BP; e.g., Heiri et al., 2015); and break 5 to the $8.2 \mathrm{ka}$ event $(8200 \mathrm{cal} \mathrm{BP}$; e.g., Tinner and Lotter, 2001; Joannin et al., 2013). This climate synopsis allows for the first time a tentative regional assessment and discussion of climate amplitude variation and its impacts on vegetation for the past 19000 years. All calculations were run with the program $\mathrm{R}$ statistics ( $\mathrm{R}$ Development Core Team, 2018). The data were plotted with the use of the programs Tilia 2.0.60 and CorelDraw.

\subsection{Biodiversity estimations and ordination analysis}

We first applied rarefaction analysis to calculate palynological richness (PRI), which is frequently used as a proxy for local to regional species richness (e.g., Birks and Line, 1992; Odgaard, 1999; Schwörer et al., 2015; Birks et al., 2016a; Rey et al., 2019a). Rarefaction analysis assesses the number of taxa per sample after setting a constant minimum terrestrial pollen sum (Birks and Line, 1992), which was 116 in our case. Subsequently, the probability of interspecific encounter (PIE; Hurlbert, 1971) was taken as a measure of palynological evenness (van 


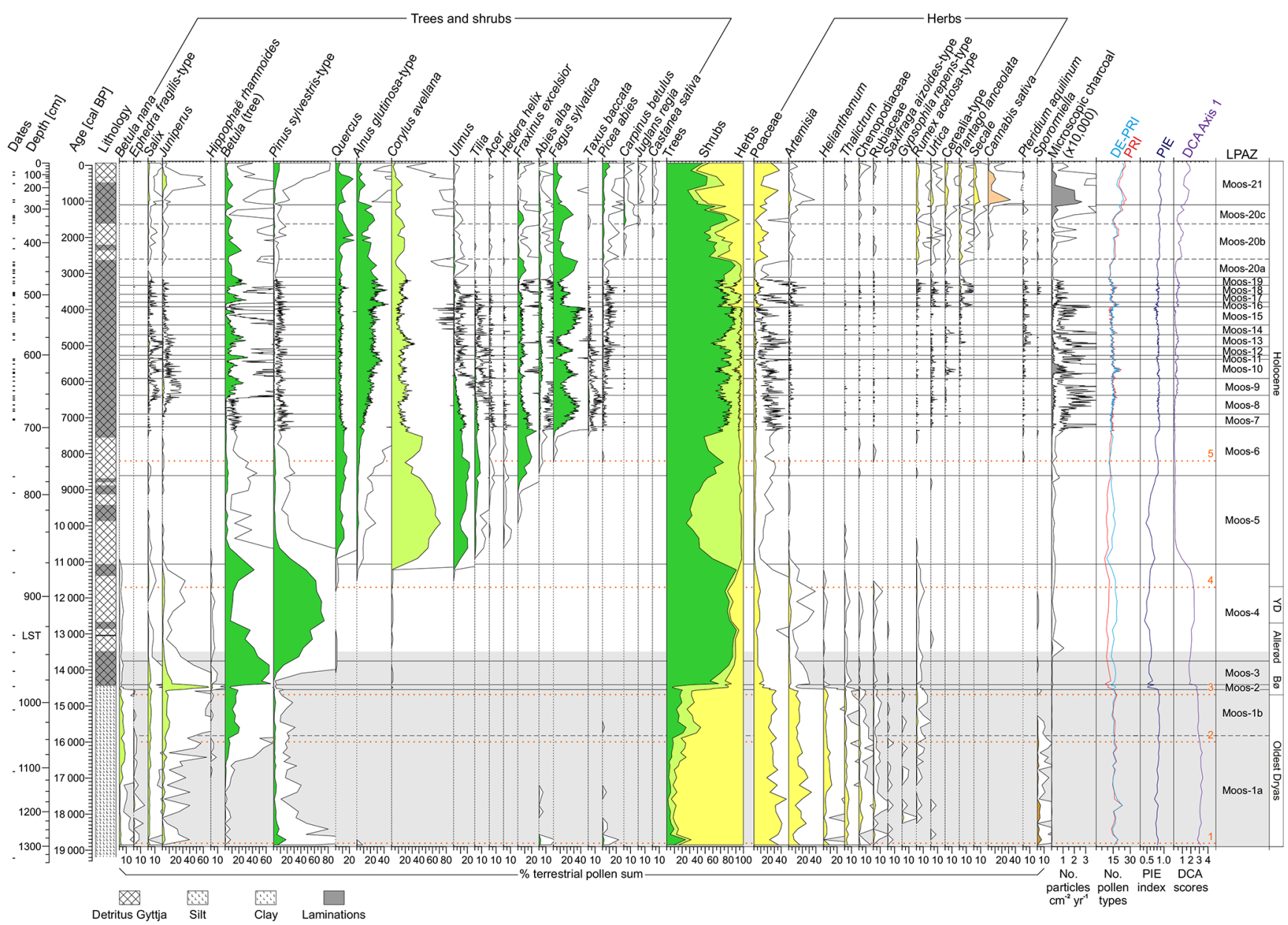

Figure 3. Moossee sediment sequence. Presented are the dates (small black lines), the lithology, percentages of selected pollen types, Pteridium aquilinum (fern spore) and Sporormiella (coprophilous fungal spore), microscopic charcoal influx values, the palynological richness (PRI; red line), the evenness-detrended palynological richness (DE-PRI; light blue line), the palynological evenness (PIE; dark blue line) as well as the detrended correspondence analysis (DCA; purple line). Empty curves show 10× exaggerations. LST: Laacher See Tephra; Bø: Bølling; YD: Younger Dryas. The horizontal light grey bar indicates the time window of Fig. 4. The orange horizontal dotted lines (1-5) mark important climatic breaks on the basis of temperature changes (Finsinger et al., 2019) and/or changing moisture availability (e.g., Joannin et al., 2013). 1: onset of the Oldest Dryas (19000 cal BP; Wirsig et al., 2016); 2: post-HE-1 warming (16000 cal BP; Samartin et al., 2012); 3: onset of the Bølling (14 700 cal BP; van Raden et al., 2013); 4: onset of the Holocene (11 700 cal BP; Heiri et al., 2015); 5: 8.2 ka event (8200 cal BP; Tinner and Lotter, 2001).

der Knaap, 2009). To assess distortion biases related to pollen production and dispersal on PRI (e.g., through high pollen producers such as Pinus sylvestris, Corylus avellana), evenness-detrended palynological richness (DE-PRI) was calculated (Colombaroli and Tinner, 2013). The aim of this procedure is to remove the evenness trend from PRI by applying an ordinary least square regression (OLS) between PRI and PIE and adding the deriving residuals (PRI - PIE) to the original PRI values (residuals + PRI). Only if PRI and DE-PRI indicate comparable trends and changes do we suppose that PRI is uninfluenced by evenness effects and thus primarily reflects species richness. The program $R$ statistics (R Development Core Team, 2018) was applied for the calculations.
We used ordination analysis (Birks and Gordon, 1985; Ter Braak and Prentice, 1988) to identify gradients in vegetation composition over time using the program Canoco 5 (Šmilauer and Lepš, 2014). We first performed a detrended correspondence analysis (DCA; Birks and Gordon, 1985) by segments without down-weighting of rare species to assess the appropriate response model (i.e., unimodal vs. linear) for our pollen percentage data. Since there is important turnover in the species composition as indicated by the rather long gradient length of the first DCA axis (3.41 SD), we retained the unimodal response model (DCA; Šmilauer and Lepš, 2014). 


\section{Results and interpretation}

\subsection{Lithology and sedimentation}

The lowermost part of the sediment sequence (1644$1300 \mathrm{~cm}, 19000 \mathrm{cal} \mathrm{BP}$ and older), which was not analyzed for pollen and microscopic charcoal, consists of clay and sand layers. From $1300 \mathrm{~cm}(19000 \mathrm{calBP})$ upward, the sediment content changes to silty clay without sand layers until $980.5 \mathrm{~cm}(14400 \mathrm{calBP})$. According to the age-depth model (Fig. 2), the sedimentation rate steadily decreases at the same time, suggesting the establishment of relatively stable soil conditions shortly after deglaciation. From $980.5 \mathrm{~cm}(14400 \mathrm{cal} \mathrm{BP})$ to the top, the sediment consists of calcite-rich fine detritus gyttja. Between 712 and $429 \mathrm{~cm}(7550-2650 \mathrm{cal} \mathrm{BP}$; Rey et al., 2019a, b) the sediment is continuously varved. Some additional partly laminated sections are present at $980.5-768 \mathrm{~cm}(14400$ $8900 \mathrm{cal} \mathrm{BP})$ and at $415-134 \mathrm{~cm}(2350-300 \mathrm{cal} \mathrm{BP})$. The sedimentation rate becomes fairly stable from $980.5 \mathrm{~cm}$ $(14,400 \mathrm{cal} \mathrm{BP})$ onward and stays more or less constant until $429 \mathrm{~cm}$ ( $2650 \mathrm{cal} \mathrm{BP})$. This stabilization is probably linked to forests growing in the catchment reducing the total erosional input. The uppermost $429 \mathrm{~cm}$ ( $2650 \mathrm{cal} \mathrm{BP}$ to the present) are characterized by a steep increase in the sedimentation rate, which is most likely related to increased erosion in response to forest openings and agricultural activities in the catchment of the lake.

\subsection{Vegetation and fire history}

The pollen sequence (Fig. 3) is subdivided into 21 local pollen assemblage zones (LPAZ) and five subzones (Moos1a, 1b, 20a, 20b and 20c). The high number of statistically significant zones, especially in the upper part of the diagram (i.e., at 7300-2900 cal BP) is related to the exceptionally high sample resolution and the rather strong vegetation changes.

Herbaceous pollen grains from Poaceae, Artemisia, Helianthemum, Thalictrum, Chenopodiaceae, Rubiaceae and Saxifraga aizoides-type are dominant at the end of the LGM (climatic break 1, ca. 19000-18 800 cal BP, LPAZ Moos 1a; Wirsig et al., 2016; Finsinger et al. 2019). This indicates the establishment of open steppe-tundra vegetation in the region including some first pioneer dwarf shrubs such as Salix herbacea (macrofossils found; Table 1), quickly after deglaciation. The increased pollen percentages of Pinus sylvestris-type (up to $18 \%$ ) may be interpreted as longdistance transport from forested, formerly unglaciated areas, and single grains of Abies alba and Picea abies might point to reworking processes probably due to persisting meltwater influence of the retreating Rhône glacier. High values of Sporormiella (percentages up to $6 \%$, influx up to 35 spores $\mathrm{cm}^{-2} \mathrm{yr}^{-1}$; Fig. 4) as a proxy for local grazing (van Geel, 2006) may be indicative of the presence of Pleistocene megafauna such as Mammuthus primigenius (woolly mammoth), Coelodonta antiquitatis (woolly rhinoceros), Rangifer tarandus (reindeer) and others that were preferentially living in the cold steppe environment at that time (e.g., Nielsen, 2013). Charcoal influx values are extremely low $\left(<50\right.$ particles $\left.\mathrm{cm}^{-2} \mathrm{yr}^{-1}\right)$, suggesting rare or almost no fire activity in the region due to scarce vegetation cover.

From 18800 to 16000 cal BP (between climatic breaks 1 and 2; LPAZ Moos-1a), the pollen record indicates that an open, species-rich (see Gypsophila repens-type and Rumex acetosa-type pollen curves), herb-dominated steppe tundra persisted around Moossee. A first slight increase in shrub pollen percentages (from $7 \%$ to $14 \%$ ) mainly from Betula nana, Salix, Juniperus and Ephedra fragilis-type suggests that patches of dwarf shrubs became established in the region after $17000 \mathrm{cal} \mathrm{BP}$. This is underlined by findings of Betula nana remains (Table 1). Sporormiella values remain high (at $1 \%-5 \%$ or around 20 spores $\mathrm{cm}^{-2} \mathrm{yr}^{-1}$ ) and Cercophora values peak (at $2.5 \%$ or 20 spores $\mathrm{cm}^{-2} \mathrm{yr}^{-1}$; Fig. 4), pointing to the prevalence of wild animals grazing at the lake. Charcoal influx values stay low (10-40 particles $\mathrm{cm}^{-2} \mathrm{yr}^{-1}$ ), suggesting that regional fires were still absent.

Pollen percentages of tree Betula markedly increase (values up to $21 \%$ ) after the end of HE-1 (climatic break 2) during LPAZ Moos-1b (16000-14600 cal BP), suggesting the regional establishment of tree Betula stands or woods. Shrub pollen percentages (i.e., Betula nana, Ephedra fragilis-type, Salix, Juniperus and Hippophaë rhamnoides) stay at 12\%-20\%, whereas non-arboreal pollen (NAP) values decrease but remain very high $(55 \%-75 \%$; see pollen percentages of Artemisia, Helianthemum, Thalictrum and Chenopodiaceae). This change points to an expansion of shrub tundra with Betula nana, Salix, Juniperus and some small-growing Betula trees into the catchment of Moossee and is likely related to climate warming after $16200 \mathrm{cal} \mathrm{BP}$ (Samartin et al., 2012; Finsinger et al., 2019). The values of Sporormiella and Cercophora diminish and fade out at the same time, suggesting that some of the megaherbivores producing a lot of dung (e.g., Mammuthus primigenius) may have become extinct locally (Nielsen, 2013; Cupillard et al., 2015). Charcoal influx remains at low values $(<$ 40 particles $\mathrm{cm}^{-2} \mathrm{yr}^{-1}$ ), indicating that despite higher total biomass and fuel availability, regional fire activity did not increase.

Pollen data suggest that at the onset of the Bølling warming at ca. 14700 cal BP (climatic break 3; van Raden et al., 2013; Finsinger et al., 2019), juniper shrub thickets or woods expanded (Juniperus pollen percentages $>65 \%$ ) as did other woody taxa (peaks of Hippophaë rhamnoides and Salix pollen), leading to the gradual replacement of shrub and steppe tundra by boreal birch-pine forests (LPAZ Moos-2, ca. 14600-14 400 cal BP; Fig. 3). Mixed Juniperus shrublands persisted for the subsequent 150200 years until the onset of a marked expansion of tree Betula (pollen $>60 \%$ ), suggesting the establishment of 


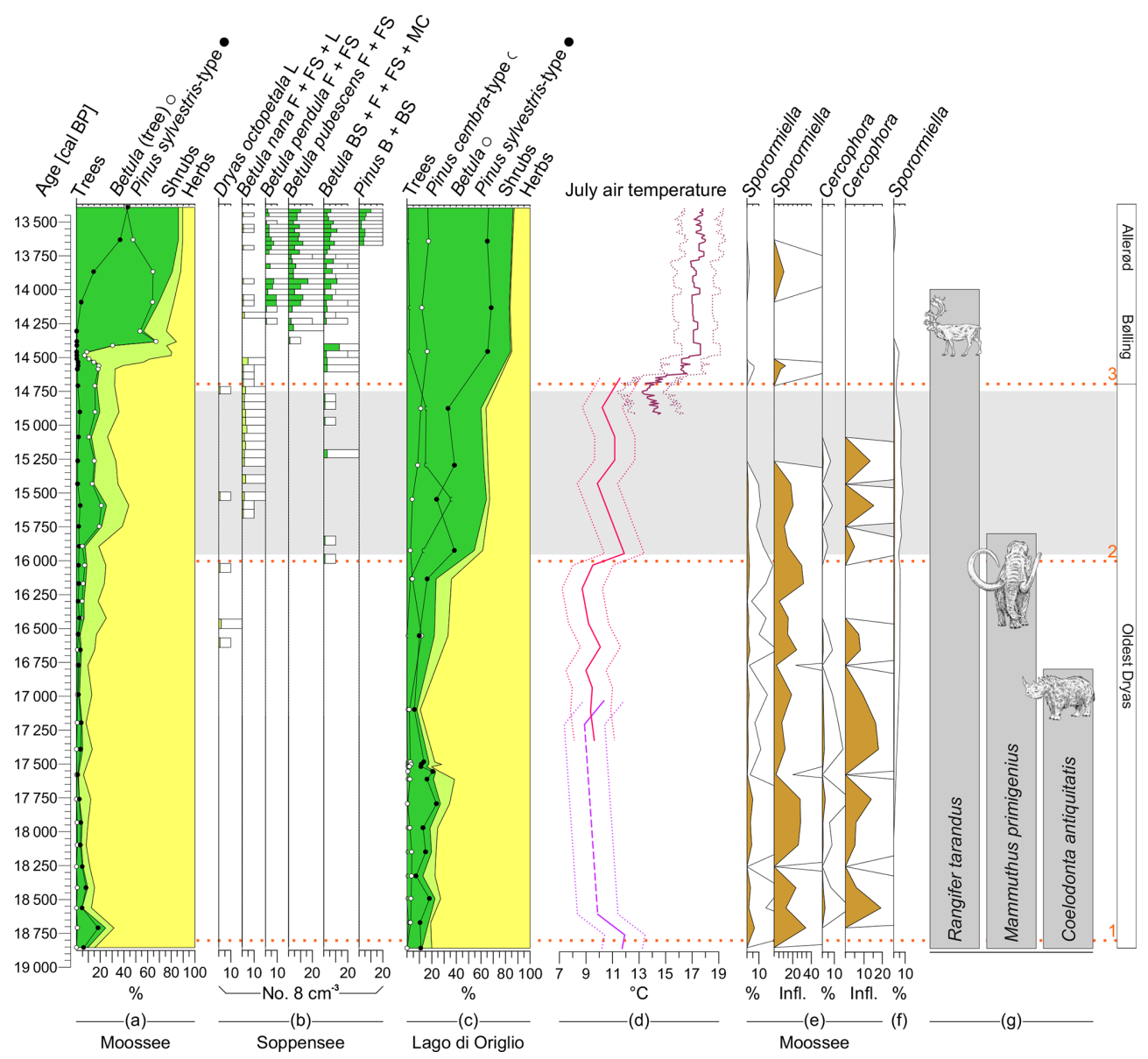

Figure 4. Composite graph. (a) Main pollen percentages of Moossee including pollen percentages of Betula(tree) and Pinus sylvestristype. (b) Concentrations of selected plant macrofossils at Soppensee (Lotter, 1999). B: bud; BS: bud scale; F: fruit; FS: fruit scale; L: leaf; MC: male catkin. (c) Main pollen percentages of Lago di Origlio including pollen percentages of Betula, Pinus sylvestris-type and Pinus cembra-type (Tinner et al., 1999). (d) Mean July air temperature estimates for the altitude of Moossee (521 m a.s.1.) using chironomid-based temperature reconstructions from Lago della Costa (light purple lines; Samartin et al., 2016), Lago di Origlio (pink lines; Samartin et al., 2012) and a chironomid-inferred stacked temperature record representing mean July air temperature estimates in the northern and central Swiss Alps (dark red lines; Heiri et al., 2015). Temperatures were corrected under the assumption of a constant modern temperature rate of $6^{\circ} \mathrm{C} \mathrm{km}^{-1}$ (Livingstone and Lotter, 1998) and plotted according to Finsinger et al. (2019). The Origlio record is only shown for the oldest part (older than $14600 \mathrm{cal}$ BP). Dotted lines reflect standard error estimates. (e) Sporormiella and Cercophora percentages and influx values (spores per square centimeter per year) of Moossee. (f) Sporormiella percentages of Burgäschisee (Rey et al., 2017). (g) Presence and extinction of important Pleistocene megafauna (Nielsen, 2013; Cupillard et al., 2015). The horizontal light grey bar indicates the time window of local archeological findings (reindeer hunter camps; Bullinger et al., 1997; Harb, 2017; Nielsen, 2018). Empty curves show 10x exaggerations (b, e, f). The orange horizontal dotted lines (1-3) mark important climatic breaks on the basis of temperature changes (Finsinger et al., 2019). 1: onset of the Oldest Dryas (19000 cal BP; Wirsig et al., 2016); 2: post-HE-1 warming (16000 cal BP; Samartin et al., 2012); 3: onset of the Bølling (14700 cal BP; van Raden et al., 2013).

birch forests around Moossee (ca. 14400-13750 cal BP, LPAZ Moos-3). This birch forest expansion resulted in an essential change in lithology (see Sect. 4.1). Subsequently, pollen of Pinus sylvestris-type steadily increases, suggesting the establishment of birch-pine forest around the lake (LPAZ Moos-4, 13 750-11 050 cal BP). These boreal forests prevailed through the Allerød warm period (13900$12900 \mathrm{cal}$ BP; van Raden et al., 2013), the subsequent Younger Dryas cooling (12 700-11 $700 \mathrm{cal}$ BP; Finsinger et al., 2019) and during the first centuries of the Holocene, as suggested by the pollen assemblages. However, the dominance of Pinus sylvestris-type and the decrease in Betula pollen after $12900 \mathrm{cal}$ BP, followed by an increase in herb pollen ( $\leq 20 \%$; see Poaceae, Artemisia) and Juniperus pollen $(2 \%-3 \%)$, points to a transformation of closed mixed boreal forests into more open, pine-dominated parklands. We interpret this change as a consequence of climate cooling during the Younger Dryas. Sporormiella fungal spores 
only occur sporadically, which might indicate low grazing activity in the close vicinity of the lake. Charcoal influx values increase temporarily $\left(>1000\right.$ particles $\left.\mathrm{cm}^{-2} \mathrm{yr}^{-1}\right)$ at the onset of mixed birch-pine forest formation and remain at stable values ( $>100$ particles $\mathrm{cm}^{-2} \mathrm{yr}^{-1}$ ), suggesting slightly enhanced fire activity after $13400 \mathrm{cal} \mathrm{BP}$.

The re-establishment of closed mixed birch-pine forests occurred shortly after the onset of the Holocene (climate break 4, ca. $11700 \mathrm{cal}$ BP; Heiri et al., 2015; Finsinger et al., 2019) as indicated by the increase in arboreal pollen $(>80 \%)$. Continuous curves of Quercus, Alnus glutinosa-type, Corylus avellana and Ulmus pollen suggest the presence of the first temperate forest stands likely in response to the Holocene climate warming already at ca. 11700-11500 cal BP. However, temperate trees and shrubs (i.e., Quercus, Corylus avellana, Ulmus, Tilia, Acer and Hedera helix) expanded only after ca. $11100 \mathrm{cal}$ BP (LPAZ Moos-5, 11050-8600 cal BP) as indicated by the pollen percentages, replacing the boreal forests within ca. 200-400 years (decrease in tree Betula and Pinus sylvestris-type pollen). This continental open forest and shrub vegetation was advantaged by the continental climate with hot and dry summers of the Early Holocene (Tinner and Lotter, 2001; Heiri et al., 2015). However, at 90008600 cal BP, Fraxinus excelsior pollen percentages increase and tree pollen indicative of mixed oak forests (Quercus, Ulmus, Tilia, Acer and Fraxinus excelsior, e.g., Welten, 1982) reaches its highest values. Charcoal influx values remain low (Fig. 3), suggesting no significant increase in fire activity during the Early Holocene.

During LPAZ Moos-6 (8600-7250 cal BP), Corylus avellana declined, and less heliophilous trees such as Fraxinus excelsior and Tilia expanded. Likely in response to climate change around $8200 \mathrm{cal} \mathrm{BP}$ (climatic break 5, onset of Mid Holocene), Abies alba and Fagus sylvatica pollen reach their empirical limit (i.e., continuous curves at 8400 and $8200 \mathrm{cal} \mathrm{BP}$, respectively), suggesting the local establishment of the first stands of these tree species (Birks and Tinner, 2016). At the same time, Alnus glutinosatype pollen percentages are steadily increasing, whereas percentages values of mixed oak forest and Corylus avellana start to decline. The pollen assemblages suggest that the decline in heliophilous deciduous forests continued after 7250 cal BP (LPAZ Moos-7 to 8, 7250-6400 cal BP), when mixed beech-silver-fir forests expanded massively. The general prevalence of mesophilous tree species throughout LPAZ Moos-7 to LPAZ Moos-21 was likely caused by a gradual shift towards more oceanic climate conditions during the Mid-Late Holocene (Tinner and Lotter, 2001, 2006), as, for example, reconstructed on the basis of higher lake levels (Magny, 2013; Joannin et al., 2013). However, this longterm dominance of dark mesophilous mixed beech-silverfir forests and the replacement of the formerly widespread mixed oak-linden-elm-maple forests was also influenced by agricultural activities, starting as early as 7000 cal BP (first pollen grains of cultural indicators such as Cerealia-type and Plantago lanceolata).

The pollen stratigraphy indicates a stepwise intensification of land use over the millennia with NAP (including cultural indicator pollen) peaking at $5600 \mathrm{calBP}$ (LPAZ Moos10, Neolithic), 3850 cal BP (LPAZ Moos-16, Early Bronze Age), 3500 cal BP (LPAZ Moos-18, Middle Bronze Age), $2600 \mathrm{cal}$ BP (LPAZ Moos 20b, Iron Age), $1800 \mathrm{cal} \mathrm{BP}$ (LPAZ Moos 20b, Roman period), 700 cal BP (LPAZ Moos 21, Middle Ages) as well as 200 cal BP (LPAZ Moos 21, modern times). Each of these land-use phases was generally accompanied by a decrease in tree pollen percentages of late successional Fagus sylvatica and Abies alba and by the expansion of light-demanding pioneers such as Betula trees and Corylus avellana shrubs. Mixed beech forests were able to recover after disturbances as suggested by the cyclical shape of the Fagus sylvatica curve. However, less resilient trees such as Tilia, Ulmus, Taxus baccata and the liana Hedera helix could not cope with the repeated forest disruptions mainly through logging, browsing, pollarding and massively increased fire disturbance (Rey et al., 2019a for more details) and were strongly reduced or even disappeared after 4500 to 3500 cal BP.

Most striking are the massive forest openings during the Iron Age and Roman period ( $>30 \%$ NAP, LPAZ Moos 20b, 2600-1600 cal BP) and from the Middle Ages onward (> $60 \%$ NAP, LPAZ Moos 21, 1050 cal BP-today) which we interpret as the influence of large settlements or urban centers within close proximity $(<8 \mathrm{~km})$ of the lake. The related strong increases in Quercus pollen percentages might point to forest management favoring oak for construction and forest pasture (acorn feeding; e.g., Gobet et al., 2000; Wick, 2015). Sporadic Sporormiella fungal spores suggest pastoral farming close to the lake. Charcoal influx values generally follow the land-use phases, showing two major peaks at 5600 and $700 \mathrm{cal} \mathrm{BP}$, pointing to two phases of highest fire activity during the past 19000 years (with up to 26000 particles $\mathrm{cm}^{-2} \mathrm{yr}^{-1}$ ). The close link to pollen of crops and weeds as well as the related declines in forests suggest that anthropogenic burning was related to slash-and-burn activities or maintenance of open fields (Tinner et al., 2005).

\subsection{Biodiversity reconstruction and ordination}

PRI and DE-PRI are very similar suggesting that overall, PRI is likely unaffected by evenness effects (Fig. 3). The agreement is particularly good during the periods 18900 $14500 \mathrm{cal} \mathrm{BP}$ and $8600 \mathrm{calBP}$ to the present. Here, both PRI and DE-PRI fluctuate slightly around 15 pollen types per sample. Palynological evenness as inferred from PIE is stable (PIE at 0.8-0.9) in phases where PRI and DEPRI are in agreement. Significantly lower values (PIE down to 0.5 ) are recorded from 14500 to $8600 \mathrm{calBP}$ when pollen grains from few taxa are dominant (either Juniperus, Betula, Pinus sylvestris-type or Corylus avellana). There, 
palynological richness drops (PRI $<10$ pollen types per sample), whereas DE-PRI stays stable at around 15 pollen types per sample. We thus assume that evenness distortions lead to underestimations of species richness during the period of strong Juniperus, Betula, Pinus (ca. 14500$11100 \mathrm{cal} \mathrm{BP})$ and Corylus dominance $(10800-9000 \mathrm{cal} \mathrm{BP}$; Fig. 3) and that such evenness distortions can be corrected by considering DE-PRI.

Both richness values (PRI, DE-PRI) generally increase (up to 20-25 pollen types per sample) during phases with higher human impact around 5650, at $4650 \mathrm{cal} \mathrm{BP}$, around 3850 and $3500 \mathrm{cal} \mathrm{BP}$ as well as after $2600 \mathrm{cal} \mathrm{BP}$. These increases are directly linked to human-induced forest openings and the introduction of cultivated plants (e.g., Cerealia-type) as well as the expansion of weeds (e.g., Plantago lanceolata), apophytes (e.g., Urtica) and heliophilous shrubs (e.g., Corylus avellana). Interestingly, the tundra phase (18900$14600 \mathrm{cal} \mathrm{BP}$ ) was also fairly species-rich suggesting that PRI and DE-PRI are correlated with openness. A rather low share $(25.6 \%)$ of the total pollen data variance is explained by DCA axis 1 . Nevertheless, the DCA scores might indicate a signal of openness as the DCA axis 1 goes almost in line with the non-arboreal pollen (NAP) and Poaceae percentages as well as DE-PRI (Fig. 3).

\section{Discussion}

\subsection{Vegetation and fire dynamics from the last deglaciation to the Mid Holocene}

The extent of the ice sheet around the Alpine arch during the LGM has been thoroughly studied in the past and the results are available as high-quality maps (e.g., Ehlers and Gibbard, 2004; Fig. 1a). Radiocarbon dates on terrestrial plant remains preserved in the bottom part of lake sediment sequences can be used to track the onset of deglaciation (Wirsig et al., 2016; Rey et al., 2017). At Moossee, the earliest date gives a calibrated age of $19200 \mathrm{cal} \mathrm{BP}$ (Table 1), which is well in line with the results from other locations around the Alps (Table 2). The unpublished basal dates of Lago di Monate (lab. code BE-8023.1.1) and Gola di Lago (lab. code BE-12286.1.1) derive from new lake sediment cores that are currently under investigation. Interestingly, most of the sites (including Moossee) with calibrated ages older than $18000 \mathrm{cal}$ years were located rather close to the margin of the former ice sheet (Fig. 1a; Table 2) and below $<500 \mathrm{~m}$ of ice (Bini et al., 2009). In contrast, sites with younger radiocarbon ages $(17270-17820 \mathrm{cal} \mathrm{BP}$; e.g., Lotter and Zbinden, 1989; Tinner et al., 1999; Ravazzi et al., 2014) were either situated below a thicker ice sheet (750$1000 \mathrm{~m}$ ) or higher up (Gola di Lago: ca. $970 \mathrm{~m}$ a.s.l.), and generally further away from the glacier tongues. However, the relatively small age difference between all these sites suggests that the collapse of the ice sheet in the peri-Alpine belt occurred within 1000-1500 years, starting not later than
$19300 \mathrm{cal} \mathrm{BP}$ at the end of the LGM $(23000-19000 \mathrm{cal} \mathrm{BP}$ for the Alps; Kaltenrieder et al., 2009; Hughes et al., 2013; Samartin et al., 2016). The huge loss of ice masses and the sudden retreat of glaciers were likely controlled by increasing summer insolation (Berger and Loutre, 1991) as well as constantly rising $\mathrm{CO}_{2}$ and $\mathrm{CH}_{4}$ concentrations in the atmosphere (Lourantou et al., 2010).

The pollen assemblage shows that pioneer plants colonized the bare grounds around Moossee shortly after glacial retreat (ca. $19000 \mathrm{cal} \mathrm{BP}$ ) to quickly form open, species-rich and herb-dominated steppe tundra communities (see biodiversity estimations and DCA in Fig. 3). First, arboreal plants (i.e., dwarf shrubs) could become established contemporaneously as indicated by a Salix herbacea leaf and Betula nana plant remains (Table 1). Comparable vegetation patterns were found at several other sites north of the Alps (e.g., Welten, 1982; Ammann, 1989; Hadorn, 1992; Duprat-Oualid et al., 2017), although only a few have radiocarbon-dated macrofossils of dwarf shrubs such as at Soppensee (Dryas octopetala leaves, Lotter, 1999; Fig. 4), Wauwilermoos (twiglet of Ericaceae; Beckmann, 2004) and Burgäschisee (unidentified arboreal twiglets; Rey et al., 2017) older than $18000 \mathrm{cal} \mathrm{BP}$. South of the Alps, and close to the LGM refugia (eastern Po Plain; Kaltenrieder et al., 2009), Juniperus shrublands spread on formerly glaciated areas above $400 \mathrm{~m}$ a.s.l. (e.g., Tinner et al., 1999, Juniperus stomata around $17500 \mathrm{cal} \mathrm{BP}$, high pollen values before $18000 \mathrm{cal} \mathrm{BP})$, possibly as a result of climate warming $\left(+2.5-3^{\circ} \mathrm{C}\right.$ ) around ca. $18800 \mathrm{cal} \mathrm{BP}$ (Samartin et al., 2016; Finsinger et al., 2019). Post-LGM climate warming may also have triggered tree species expansions south of the Alps at altitudes $\leq 350 \mathrm{~m}$ a.s.1. (Larix decidua, Pinus sp. and Betula) between 17500 and $16000 \mathrm{cal}$ BP (Finsinger et al., 2006; Monegato et al., 2007).

North of the Alps, a first important vegetation shift after the establishment of the steppe tundra occurred at ca. $16000 \mathrm{cal}$ BP with the expansion of shrub tundra around Moossee (see pollen of tree Betula, Betula nana, Juniperus and Salix, macrofossils of Betula nana). A similar vegetation shift has been recorded elsewhere in the central European lowlands (Duprat-Oualid et al., 2017; Rey et al., 2017), pointing to a regional establishment of shrub tundra with probably some first tree birch stands. Plant macrofossil data from Soppensee (Lotter, 1999; Fig. 4) suggest a coeval establishment of dwarf-birch thickets on the Swiss Plateau, while several records of Welten (1982) point to increasing Betula abundances. Indeed, the chironomidinferred July temperature estimates from Lago di Origlio (Samartin et al., 2012, corrected to the altitude of Moossee $521 \mathrm{~m}$ a.s.l. assuming a constant modern temperature rate of $6{ }^{\circ} \mathrm{C} \mathrm{km}^{-1}$; Livingstone and Lotter, 1998), indicate a July air temperature warming of $2-2.5^{\circ} \mathrm{C}$ reaching temperatures of $10-11.5^{\circ} \mathrm{C}$ that are suitable for tree growth (Lang, 1994) after $16000 \mathrm{cal} \mathrm{BP}$, even considering the latitudinal temperature gradient (Figs. 4 and 5, Samartin et al., 
Table 2. Oldest radiocarbon dates from terrestrial plant remains found in sediment sequences from lakes north and south of the Alps. Uncertainties in ${ }^{14} \mathrm{C}$ ages refer to $68 \%$ probabilities $(1 \sigma)$, whereas ranges of calibrated ages represent $95 \%$ probabilities $(2 \sigma)$.

\begin{tabular}{|c|c|c|c|c|c|c|}
\hline $\begin{array}{l}\text { Code } \\
\text { (Fig. 1a) }\end{array}$ & Site name & Reference & ${ }^{14} \mathrm{C}$ age $(\mathrm{BP}){ }^{\mathrm{a}}$ & $\begin{array}{r}\text { Age } \\
(\mathrm{cal} \mathrm{BP})^{\mathrm{b}}\end{array}$ & $\begin{array}{r}\text { Age } \\
\text { range }(\mathrm{cal} \mathrm{BP})^{\mathrm{b}}\end{array}$ & Material \\
\hline M & Moossee & This work & $15900 \pm 130$ & 19180 & $18890-19520$ & Salix herbacea leaf, rhizome indet \\
\hline 1 & Burgäschisee & Rey et al. (2017) & $15380 \pm 70$ & 18660 & $18490-18800$ & Twiglet indet \\
\hline 2 & Wauwilermoos & Beckmann (2004) & $15300 \pm 130$ & 18560 & $18260-18830$ & Ericaceae twig \\
\hline 3 & Soppensee & $\begin{array}{l}\text { Hajdas et al. (1993), } \\
\text { Lotter (1999) }\end{array}$ & $14190 \pm 120$ & 17270 & $16900-17620$ & Terrestrial plant remains indet \\
\hline 4 & Rotsee & Lotter and Zbinden (1989) & $14600 \pm 200$ & 17770 & $17250-18270$ & Terrestrial plant remains indet \\
\hline 5 & Zürichsee & Lister (1988) & $14600 \pm 250$ & 17760 & $17110-18370$ & Twiglet indet \\
\hline 6 & $\begin{array}{l}\text { Lago Piccolo } \\
\text { di Avigliana }\end{array}$ & $\begin{array}{l}\text { Larocque and } \\
\text { Finsinger (2008) }\end{array}$ & $14930 \pm 80$ & 18150 & $17930-18360$ & Wood indet \\
\hline 7 & Lago di Monate & This work & $16000 \pm 250$ & 19310 & 18780-19930 & Deciduous leaf fragments indet \\
\hline 8 & Lago di Origlio & $\begin{array}{l}\text { Tinner et al. (1999), } \\
\text { Samartin et al. (2012) }\end{array}$ & $14520 \pm 80$ & 17700 & $17480-17930$ & Wood indet \\
\hline 9 & Gola di Lago & This work & $14640 \pm 70$ & 17820 & $17610-18010$ & Deciduous leaf, twig fragments \\
\hline 10 & Lago d'Iseo & Lauterbach et al. (2012) & $14950 \pm 130$ & 18180 & $17870-18500$ & Terrestrial plant remains indet \\
\hline 11 & Lago di Garda & Ravazzi et al. (2014) & $14350 \pm 70$ & 17490 & $17220-17710$ & Ніррорһаё seed, leaf fragment indet \\
\hline 12 & Lago di Ragogna & Monegato et al. (2007) & $14490 \pm 130$ & 17660 & $17310-17980$ & Larix and Pinus remains \\
\hline
\end{tabular}

${ }^{\text {a }}$ Stuiver and Polach (1977). ${ }^{\text {b }}$ Stuiver and Reimer (1993), Reimer et al. (2013).

2012; Finsinger et al., 2019). Other factors than summer temperatures such as cold air extrusions from the still existing Scandinavian ice sheet in the north and a stronger latitudinal temperature gradient (Heiri et al., 2014) may have prevented the establishment of dense Betula forests north of the Alps (Rey et al., 2013). Indeed, south of the Alps, in more sheltered positions, widespread afforestation with Pinus cembra and Larix decidua started at around 16500$16000 \mathrm{cal} \mathrm{BP}$ (e.g., Tinner et al., 1999; Hofstetter et al., 2006; Vescovi et al., 2007; Pini et al., 2016; Fig. 4). At the same time, sites above $1000 \mathrm{~m}$ a.s.l. became ice-free but remained unforested (Vescovi et al., 2007; Pini, 2002), with treeline positions around $800-1000 \mathrm{~m}$ a.s.l. (Vescovi et al., 2007).

High and almost continuous abundances of coprophilous Sporormiella and Cercophora spores from the onset of the Moossee record until ca. $15250 \mathrm{cal}$ BP could be indicative of Pleistocene megaherbivores (e.g., Mammuthus primigenius, Coelodonta antiquitatis, Rangifer tarandus). Similar results are recorded at Burgäschisee (Rey et al., 2017; Fig. 4) and fit in well with numerous finds of remains of these animals (e.g., bones, tusks, antlers) in the region (Nielsen, 2013; Cupillard et al., 2015). On-site hunter camps located at the former lake shore of Moossee (Fig. 1b), dated to 1695014750 cal BP (14 000-12 800 cal BCE; Harb, 2017; Nielsen, 2018), suggest intense hunting. Hunting combined with climate warming may have caused the regional extinctions of Mammuthus primigenius, Coelodonta antiquitatis and Rangifer tarandus during the Late Glacial (Nielsen, 2013; Cupillard et al., 2015), as also evidenced by decreasing numbers of dung spores after 15500 cal BP (Fig. 4).

Juniper shrublands expanded massively at Moossee after ca. $14600 \mathrm{cal} \mathrm{BP}$ (onset of the Bølling), which is in agreement with the well-dated pollen record at Gerzensee (van Raden et al., 2013). Only ca. 200 years later, Betula forests took over and completed the initial afforestation which is widely recorded in pollen assemblages across the Swiss Plateau (e.g.; Ammann, 1989; Rey et al., 2017) and unambiguously confirmed by Betula pubescens and $B$. pendula macroremains at Soppensee (Lotter, 1999; Fig. 4). Contemporaneously, sites up to $1800 \mathrm{~m}$ a.s.l. in the Alps turned ice-free (Welten, 1982; Ilyashuk, et al., 2009). South of the Alps, dense boreal forests with Pinus sylvestris and Betula became established in the lowlands (Vescovi et al., 2007) and the tree line reached at least $1850 \mathrm{~m}$ a.s.l. (Tinner and Vescovi, 2007; Marta et al., 2013). This rapid deglaciation in the Alps and the forest expansion in southern and central Europe was caused by a sudden ca. $4{ }^{\circ} \mathrm{C}$ warming, as indicated by chironomid and stable isotope records (von Grafenstein et al., 1998, 1999; North Greenland Ice Core Project members, 2004; Heiri and Millet, 2005; Larocque and Finsinger, 2008; Fleitmann et al., 2009; Fig. 5).

After ca. $13600 \mathrm{cal}$ BP (during the Allerød) mixed birchpine forests were spreading at Moossee and all across 


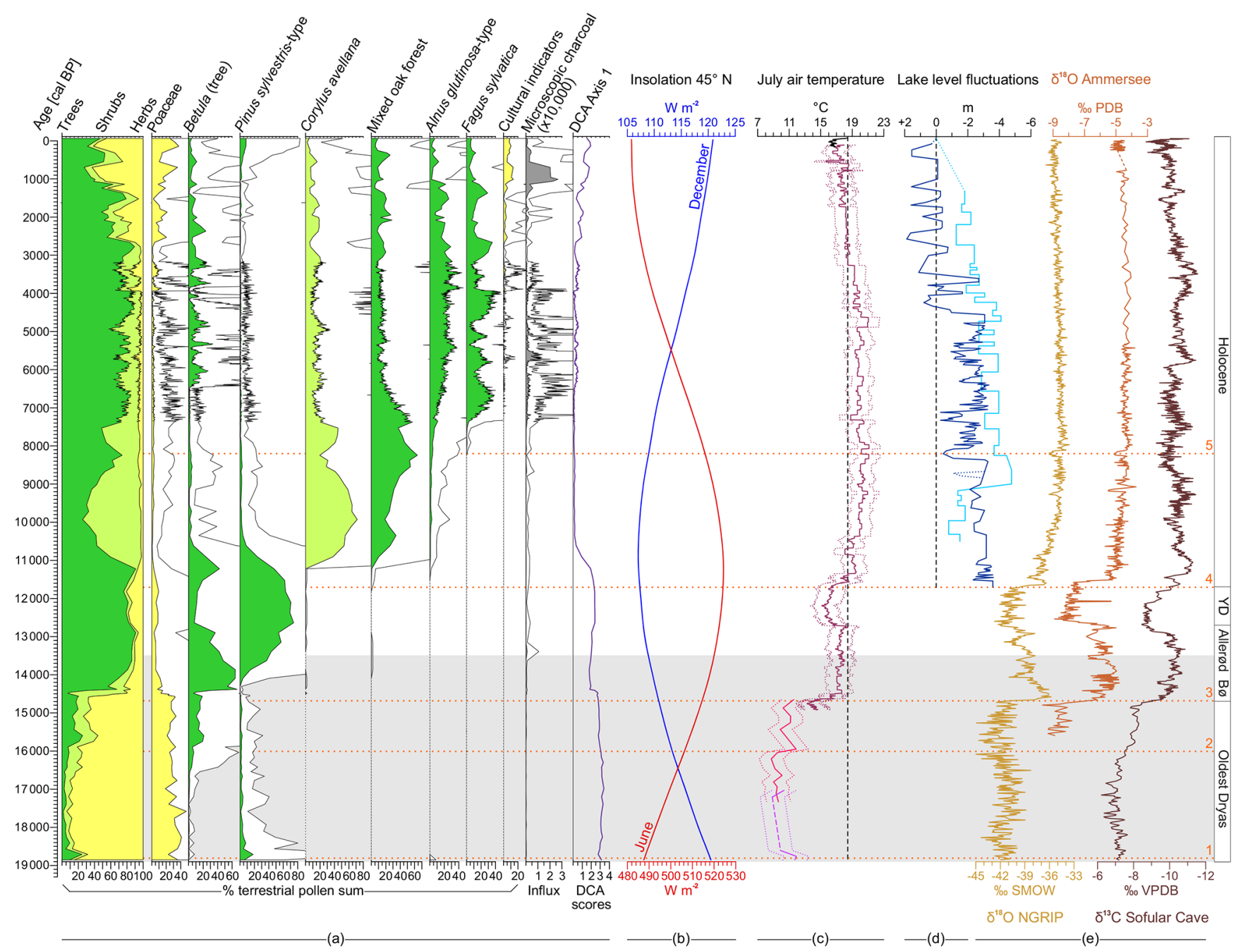

Figure 5. Composite graph. (a) Selected pollen percentages, microscopic charcoal influx values (particles $\mathrm{cm}^{-2} \mathrm{yr}^{-1}$ ) and the detrended correspondence analysis (DCA; purple line) of Moossee. Mixed oak forest $=\Sigma$ Quercus + Ulmus + Fraxinus excelsior + Tilia + Acer . Cultural indicators $=\Sigma$ Cerealia-type + Plantago lanceolata. Empty curves show 10x exaggerations. (b) June (red line) and December (blue line) insolation for $45^{\circ} \mathrm{N}$ (Berger and Loutre, 1991). (c) Mean July air temperature estimates for the altitude of Moossee (521 ma.s.1.) using chironomid-based temperature reconstructions from Lago della Costa (light purple lines; Samartin et al., 2016), Lago di Origlio (pink lines; Samartin et al., 2012) and a chironomid-inferred stacked temperature record representing mean July air temperature estimates in the northern and central Swiss Alps (dark red lines; Heiri et al., 2015). Additionally, historical (1755-2018 CE) 30-year moving average July air temperature measurements from Basel-Binningen (black line) are shown. Temperatures were corrected under the assumption of a constant modern temperature rate of $6^{\circ} \mathrm{C} \mathrm{km}^{-1}$ (Livingstone and Lotter, 1998) and plotted according to Finsinger et al. (2019). The black vertical dashed line indicates today's average July air temperatures $\left(18.3^{\circ} \mathrm{C}\right)$ in Bern-Zollikofen (MeteoSwiss, 2017). The Origlio record is only shown for the oldest part (older than $14600 \mathrm{cal} \mathrm{BP}$ ). Dotted lines reflect standard error estimates. (d) Relative lake level reconstructions of Lac de Cerin (light blue line; Magny et al., 2011) and Lago di Ledro (dark blue line; Magny et al., 2012). The black vertical dashed line marks today's lake levels. (e) Stable isotopes records from NGRIP (light brown line; North Greenland Ice Core Project members, 2004), Ammersee (dark orange line; von Grafenstein et al., 1998, 1999) and Sofular Cave (brown line; Fleitmann et al., 2009). The horizontal light grey bar indicates the time window of Fig. 4. The orange horizontal dotted lines (1-5) mark important climatic breaks on the basis of temperature changes (Finsinger et al., 2019) and/or increased moisture availability (e.g., Joannin et al., 2013). 1: onset of the Oldest Dryas (19000 cal BP; Wirsig et al., 2016); 2: post-HE-1 warming (16000 cal BP; Samartin et al., 2012); 3: onset of the Bølling (14 700 cal BP; van Raden et al., 2013); 4: onset of the Holocene (11 700 cal BP; Heiri et al., 2015); 5: 8.2 ka event (8200 cal BP; Tinner and Lotter, 2001). B $\varnothing$ : B $\varnothing 1$ ling; YD: Younger Dryas. 
southern central Europe (e.g., Clark et al., 1989; Lotter, 1999). In northern Italy temperate tree stands became established, probably in response to increasing summer temperatures (Vescovi et al., 2007; Lotter et al., 2012). The early spread of temperate trees south of the Alps (e.g., Quercus, Tilia, Ulmus) is evidenced by Quercus bud scales at Lago Piccolo di Avigliana (Finsinger et al., 2006) and Lago di Ragogna (Monegato et al., 2007). Summer warming (Heiri et al., 2015; Fig. 5) may also have triggered the increase in regional forest fires observed at Moossee and elsewhere north of the Alps (Rey et al., 2017).

Boreal forests prevailed around Moossee during the Younger Dryas cold period (ca. 12 600-11 $700 \mathrm{cal} \mathrm{BP}$ ), when a summer temperature cooling of ca. $2-4^{\circ} \mathrm{C}$ north of the Alps (Lotter et al., 2000; Heiri et al., 2015; Finsinger et al., 2019; Fig. 5) initiated a recovery of cold steppe-tundra vegetation (e.g., Artemisia, Chenopodiaceae). At the same time, late successional pine trees increasingly outcompeted pioneer birch trees, forming open pine-dominated forests, a finding well supported by the macrofossil evidence (Lotter, 1999). Chironomid-based summer temperature reconstructions (Samartin et al., 2012; Heiri et al., 2014) suggest only a marginal cooling in southern Europe, which nevertheless affected temperate trees stands (Tinner et al., 1999; Finsinger et al., 2006; Vescovi et al., 2007). This different magnitude of climate cooling may be related to the sheltered location of these lakes in the lee of the Alps, preventing direct influences from the polar ice masses and the North Atlantic during the Younger Dryas (Samartin et al., 2012; Heiri et al., 2014).

After $11700 \mathrm{cal} \mathrm{BP}$ at the onset of the Holocene, boreal forests became dense in the peri-Alpine lowlands (Tinner et al., 1999; Rey et al., 2017). Chironomid-based July temperature estimates (Heiri et al., 2015; Finsinger et al., 2019), other biotic proxies (Lotter et al., 2000; Birks and Ammann, 2000) as well as oxygen isotope records (von Grafenstein et al., 1998, 1999, 2000; Schwander et al., 2000) suggest a sudden warming of $3-4{ }^{\circ} \mathrm{C}$ within only ca. 50 years (Tinner and Kaltenrieder, 2005). In response to this rapid and strong climate warming, stands of temperate trees (e.g., Quercus, Alnus, Ulmus) became established north of the Alps at 11600-11100 (Fig. 3) to gradually replace the previous mixed pine-birch forests shortly after $11100 \mathrm{cal}$ BP. By $10500 \mathrm{cal}$ BP mixed oaklinden-elm-maple forests prevailed. In the forelands of the southern Alps, the first mixed oak-linden-elm stands had become established already during the Late Glacial, so that the Early Holocene population expansions of temperate trees (e.g., Quercus, Ulmus, Tilia) were far more rapid and accomplished by ca. 11500-11300 cal BP (Tinner et al., 1999; Finsinger et al., 2006; Vescovi et al., 2007), i.e., 800-1000 years earlier than north of the Alps. This finding is in agreement with process-based dynamic vegetation simulations, which suggest that after a first establishment of boreal and temperate tree stands, population expansions usually last $500-1000$ years before coming to a (high) biomass equilibrium with climate (Lotter and Kienast, 1992; Wick and Möhl, 2006; Henne et al., 2011; Schwörer et al., 2014).

The dominance of mixed oak-linden-elm-maple forests over millennia in central Europe (e.g., Hadorn, 1992; Lotter, 1999; Litt et al., 2009; Rey et al., 2017) was most likely favored by a continental climate as indicated by maximum summer and minimum winter insolation (Berger and Loutre, 1991), $1.5-2^{\circ} \mathrm{C}$ warmer summers than today (e.g., Heiri et al., 2015) and generally drier conditions as reflected by lower lake levels (e.g., Magny et al., 2012; Fig. 5). This forest type persisted until ca. 8500-8000 cal BP (Figs. 3 and 5), when Abies alba and Fagus sylvatica tree stands became established around Moossee. Both tree species are shade-tolerant and competitive under mesophytic conditions (Tinner and Lotter, 2006; Tinner et al., 2013; Lauber et al., 2014). Similarly, Alnus and Fraxinus excelsior, both welladapted to wet soils and moist conditions (Lauber et al., 2014; Rey et al., 2017), expanded as well. The establishment and massive spread of mesophilous mixed beech forests after 7500 cal BP (see high number of Fagus sylvatica bud scales in Table 1) is well-studied on the Swiss Plateau (e.g., Lotter, 1999; Wehrli et al., 2007) and the causes for this change have been intensely discussed in the past (Tinner and Lotter, 2006). Decreasing summer temperatures (Heiri et al., 2015; Finsinger et al., 2019) and increasing moisture availability (e.g., Magny et al., 2011, 2012; Joannin et al., 2013; Fig. 5) suggest climate as the main trigger of this drastic change in central European forest composition.

\subsection{Vegetation and land-use history during the Mid and Late Holocene}

The onset of land use and agricultural activities around Moossee is documented as early as $7000 \mathrm{cal} \mathrm{BP}$ by the first cultural indicator pollen such as Cerealia-type and Plantago lanceolata (Figs. 3 and 5). Increases in microscopic charcoal, which fall into a phase with fairly closed mixed beechoak forests (Figs. 3 and 5), suggest a drastic increase in fire activity at the onset of the farming. After $6500 \mathrm{cal} \mathrm{BP}$ intensified agricultural activities caused a first dieback of the mixed beech forests. Our interpretation is in good agreement with coeval on-site archeological evidence (e.g., log boat made of Tilia wood; Hafner et al., 2012; Harb, 2017). Many lowland sites south and north of the Alps indicate a contemporaneous opening of the forests. The strong link with increasing fire activities suggests that farmers used fire to gain arable and pastoral land (i.e., slash and burn; e.g., Tinner et al., 1999; Kleinmann et al., 2015; Rey et al., 2017, 2019a). Disruption and land-use phases generated typical successional cycles starting with arboreal pioneers (Corylus avellana, tree Betula and Alnus) rapidly spreading after disturbance. These light-demanding pioneers were regularly replaced by Fraxinus excelsior and Ulmus, 
which were in turn replaced by late successional Fagus sylvatica and Abies alba (e.g., Kleinmann et al., 2015). Most strikingly, a recent high-precision and high-resolution study covering 3 millennia from the Neolithic to the Bronze Age (ca. 7000-4000 cal BP) was able to numerically demonstrate that land-use phases and the subsequent forest successions were regionally to supra-regionally synchronous (Rey et al., 2019a). The most reasonable explanation for such a striking pattern is climate and its influences on human activities. Indeed, Rey et al. (2019a) found that land-use phases generally coincided with warm and dry periods as indicated by lower lake levels in western Switzerland and eastern France (Magny, 2013) as well as higher solar irradiance (Steinhilber et al., 2009). This finding underlines that climate may have governed harvest success and through that prehistoric human population densities, an environmental effect that in the long-term was counteracted by stepwise introductions of technological innovations (e.g., metal tools, new crops; Tinner et al., 2003, Wirtz and Lemmen, 2003).

Our paleobotanical data indicate a steady intensification of agricultural activities during the Late Holocene (from ca. 3850 cal BP onward), which is primarily evidenced in regions on the Swiss Plateau that are climatically favorable for crop production (i.e., < 550 m a.s.l.; Ammann, 1989; Hadorn, 1992; Rey et al., 2017). Many tree species were strongly affected by fire disturbance, browsing and/or overexploitation, and some of them (e.g., Tilia, Taxus baccata) even collapsed completely (Rey et al., 2017). By contrast, several taxa such as Quercus and Fagus were promoted as fruit trees (Gobet et al., 2000; Wick, 2015), while others were introduced (e.g., Juglans regia, Castanea sativa) for the same reason (Tinner et al., 1999; Conedera et al., 2004). Thanks to the combined effects of open land creation and the introduction of new species, total biodiversity increased (Fig. 3), suggesting that human activities related to farming were crucial for the establishment of a mosaic of diverse communities (e.g., hay meadows, orchards, hedges). As a consequence, during the Late Holocene (i.e., the past 5000 years), humans gradually replaced climate as the driving factor of vegetation structure and composition. Woodlands became increasingly impoverished, leading to monospecific Picea, Quercus or Fagus forest communities that are best suited for timber, fuel and fodder production. The strong increase in biodiversity in open habitats (meadows, fields, hedges) thus contrasted with diversity losses in forests and woodlands (Colombaroli and Tinner, 2013). We can show that with regard to the dominant species, beech forests were able to recover even after the most intense anthropogenic disturbances (e.g., Iron Age, Roman period, Middle Ages). Therefore, central European beech may presumably prevail in the future if the amplitude of the anticipated climate warming remains within the Mid Holocene variability range (ca. $+2{ }^{\circ} \mathrm{C}$ compared to the 20 th century; Heiri et al., 2015; Finsinger et al., 2019). However, if intense forestry should decline, e.g., as a consequence of nature protection measures, more diverse forests may re-establish themselves. If climate should become $>2{ }^{\circ} \mathrm{C}$ warmer, possibly causing a reduction in moisture availability (Kovats et al., 2014; Henne et al., 2018), drought-sensitive beech may rapidly decline, giving way to unprecedented forest communities that will likely include drought-resistant deciduous species such as Quercus pubescens, droughtresistant evergreen broadleaved species such as Quercus ilex and warm-temperate conifers such as Abies alba (Bugmann et al., 2015; Henne et al., 2015, 2018).

\section{Conclusions}

We present a novel highly resolved vegetation and fire history record from central Europe that covers the entire post-LGM period. Radiocarbon dating on terrestrial plant remains (i.e., Salix herbacea leaf) resulted in a calibrated age of ca. $19200 \mathrm{cal}$ BP $(18890-19520 \mathrm{cal} \mathrm{BP}$, $95 \%(2 \sigma)$ probabilities) for the bottom of the sediment sequence. To our knowledge, together with the novel radiocarbon date from the bottom sediments of Lago di Monate of $19300 \mathrm{cal} \mathrm{BP}(18780-19930 \mathrm{cal} \mathrm{BP}, 95 \%$ $(2 \sigma)$ probabilities; Table 2$)$, this date provides the oldest age coming from peri-Alpine lakes that were created by deglaciation after the ice collapse at the end of the LGM. Deglaciation was followed by the rapid establishment of pioneer steppe vegetation. After HE-1 (end ca. 16700 cal BP; Stanford et al., 2011) shrubs (Betula nana, Juniperus, Salix) and probably trees (likely Betula pubescens, Betula pendula) expanded, which is comparable to recent ecosystem changes in the Arctic in response to ongoing global warming (Pearson et al., 2013; Brugger et al., 2019). Starting points of important vegetation reorganizations at ca. 16000 , 14600,11600 and $8200 \mathrm{cal} \mathrm{BP}$ were strongly linked to climate change (temperature and/or precipitation shifts). No apparent inertia nor lags of population establishments were detected, implying a very high sensitivity and adjustment capacity of plant communities to climatic and environmental changes at decadal scales. These rapid responses without any apparent lags (due to, e.g., migration) are explained by the very efficient distribution mechanisms of plants (e.g., winged fruits or bird transport of acorns; Firbas, 1949; Tinner and Lotter, 2006) and the proximity to the refugia $(<400 \mathrm{~km})$ of temperate and boreal species (Kaltenrieder et al., 2009; Samartin et al., 2012; Gubler et al., 2018). The onset of varved sediments ( $7000 \mathrm{cal} \mathrm{BP})$ was closely related to vegetation opening for land use. Land use gradually overrode climate as the dominant factor in determining vegetation composition and structure during the Late Holocene. Present-day beech forests have been shaped by anthropogenic disturbances over millennia and were resilient to Mid and Late Holocene climate change. However, recent climate warming may exceed the Mid and Late Holocene climate variability releasing sudden collapses 
and unprecedented reorganizations of central European ecosystems.

Data availability. The complete pollen and microscopic charcoal data sets are available through the Neotoma Paleoecology Database (https://www.neotomadb.org, last access: 22 July 2020). Pollen: https://doi.org/10.21233/6N58-K786 (Rey et al., 2020a); Microscopic charcoal: https://doi.org/10.21233/XD5R-PF83 (Rey et al., 2020b).

Author contributions. FR carried out all pollen and most of the quantitative analyses, constructed the chronology, arranged all figures and led the writing. EG initially designed the research project and helped with interpreting the data sets. CS calculated the zonation and gave important scientific input. AH obtained funding and contributed with the discussion of local and regional archeology. SS was responsible for radiocarbon dating. WT helped designing the research project, received funding and wrote major parts of the paper. All authors contributed and commended critically on the paper and gave final approval for publication.

Competing interests. The authors declare that they have no conflict of interest.

Acknowledgements. We thank Willi Tanner, Julia Rhiner, Sandra O. Brügger, Stéphanie Samartin, Lena Thöle and Petra Beffa for their valuable help during the corings, Edith Vogel for executing the radiocarbon dating, André F. Lotter for his important input into the analysis of varved lake sediments, Stamatina Makri and Julian Laabs for helping with the maps, Werner E. Stöckli for providing the idea of gaining oldest bottom lake sediment dates, Adriano Boschetti and the Beyond Lake Villages (BeLaVi) project team for constructive discussions, Jacqueline van Leeuwen for doublechecking some pollen identifications, and César Morales del Molino for his help with archiving the data sets. We are grateful to the editor Nathalie Combourieu-Nebout and three anonymous reviewers for their valuable comments on previous versions of the manuscript.

Financial support. This research has been supported by the Swiss National Science Foundation (grant no. SNF 200021_149203/1).

Review statement. This paper was edited by Nathalie Combourieu-Nebout and reviewed by three anonymous referees.

\section{References}

Adolf, C., Wunderle, C., Colombaroli, C., Weber, H., Gobet, E., Heiri, O., van Leeuwen, J. F. N., Bigler, C., Connor, S. E., Gałka, M., La Mantia, T., Makhortykh,
S., Svitavská-Svobodová, H., Vannière, B., and Tinner, W.: The sedimentary and remote-sensing reflection of biomass burning in Europe, Global Ecol. Biogeogr., 27, 199-212, https://doi.org/10.1111/geb.12682, 2018.

Ammann, B.: Late-Quaternary palynology at Lobsigensee - Regional vegetation history and local lake development, Diss. Bot., 137, 1-157, 1989.

Ammann, B. and Tobolski, K.: Vegetational development during the Late-Würm at Lobsigensee (Swiss Plateau). Studies in the late Quaternary of Lobsigensee 1, Rev. Paléobiol., 2, 163-180, 1983.

Ammann, B., van Leeuwen, J. F. N., van der Knaap, W. O., Lischke, H., Heiri, O., and Tinner, W.: Vegetation responses to rapid warming and to minor climatic fluctuations during the Late-Glacial Interstadial (GI-1) at Gerzensee (Switzerland), Palaeogeogr., Palaeoclimatol., Palaeoecol., 391, 40-59, https://doi.org/10.1016/j.palaeo.2012.07.010, 2013.

Beckmann, M.: Pollenanalytische Untersuchung der Zeit der Jäger und Sammler und der ersten Bauern an zwei Lokalitäten des Zentralen Schweizer Mittellandes, Diss. Bot., 390, 1-223, 2004.

Bennett, K. D.: Determination of the number of zones in a biostratigraphical sequence, New Phytol., 132, 155-170, https://doi.org/10.1111/j.1469-8137.1996.tb04521.x, 1996.

Berger, A. and Loutre, M. F.: Insolation values for the climate of the last 10 million years, Quaternary. Sci. Rev., 10, 297-317, https://doi.org/10.1016/0277-3791(91)90033-Q, 1991.

Beug, H.-J. (Ed.): Leitfaden der Pollenbestimmung für Mitteleuropa und angrenzende Gebiete, Pfeil, Munich, Germany, 2004.

Bini, A., Buoncristiani, J.-F., Couterrand, S., Ellwanger, D., Felber, M., Florineth, D., Graf, H. R., Keller, O., Kelly, M, Schlüchter, C., and Schoeneich, P.: Die Schweiz während des letzteiszeitlichen Maximums (LGM) 1:500 000, Bundesamt für Landestopographie swisstopo, 2009.

Birks, H. H. and Ammann, B.: Two terrestrial records of rapid climatic change during the Glacial-Holocene transition $(14,000-$ 9,000 calendar years BP) from Europe, P. Natl. Acad. Sci. USA, 97, 1390-1394, https://doi.org/10.1073/pnas.97.4.1390, 2000.

Birks, H. J. B.: The identification of Betula nana pollen, New Phytol., 67, 309-314, https://doi.org/10.1111/j.14698137.1968.tb06386.x, 1968.

Birks, H. J. B. and Gordon, A. D. (Eds.): Numerical Methods in Quaternary Pollen Analysis, Academic Press, London, UK, 1985.

Birks, H. J. B. and Line, J. M.: The use of rarefaction analysis for estimating palynological richness from quaternary pollen-analytical data, Holocene, 2, 1-10, https://doi.org/10.1177/095968369200200101, 1992.

Birks, H. J. B. and Tinner, W.: European tree dynamics and invasions during the Quaternary, in: Introduced tree species in European forests: opportunities and challenges, edited by: Krumm, F., and Vítková, L., European Forest Institute, Freiburg, Germany, 22-43, 2016.

Birks, H. J. B., Felde, V. A., Bjune, A. E., Grytnes, J.-A., Seppä, H., and Giesecke T.: Does pollen-assemblage richness reflect floristic richness? A review of recent developments and future challenges, Rev. Palaeobot. Palynol., 228, 1-25, https://doi.org/10.1016/j.revpalbo.2015.12.011, 2016a.

Birks, H. J. B., Birks, H. H., and Ammann, B.: The fourth dimension of vegetation, Science, 354, 412-413, https://doi.org/10.1126/science.aai8737, 2016b. 
Blaauw, M.: Methods and code for 'classical' age-modelling of radiocarbon sequences, Quat. Geochronol., 5, 512-518, https://doi.org/10.1016/j.quageo.2010.01.002, 2010.

Bronk Ramsey, C.: Analysis of chronological information and radiocarbon calibration: the program OxCal, Archaeol. Comput. Newsl., 41, 11-16, 1994.

Bronk Ramsey, C.: Radiocarbon calibration and analysis of stratigraphy: the OxCal program, Radiocarbon, 37, 425-430, https://doi.org/10.1017/S0033822200030903, 1995.

Bronk Ramsey, C.: Development of the radiocarbon calibration program OxCal, Radiocarbon, 43, 355-363, https://doi.org/10.1017/S0033822200038212, 2001.

Bronk Ramsey, C., van der Plicht, J., and Weninger, B.: 'Wiggle matching' radiocarbon dates, Radiocarbon, 43, 381-389, https://doi.org/10.1017/S0033822200038248, 2001.

Brugger, S. O., Gobet, E., Blunier, T., Morales-Molino, C., Lotter, A. F., Fischer, H., Schwikowski, M., and Tinner, W.: Palynological insights into global change impacts on Arctic vegetation, fire, and pollution recorded in Central Greenland ice, Holocene, 29, 1189-1197, https://doi.org/10.1177/0959683619838039, 2019.

Bugmann, H., Brang, P., Elkin, C., Henne, P. D., Jakoby, O., Lévesque, M., Lischke, H., Psomas, A., Rigling, A., Wermelinger, B., and Zimmermann, N. E.: Climate change impacts on tree species, forest properties, and ecosystem services, in: CH2014-impacts, toward quantitative scenarios of climate change impacts in Switzerland, edited by: Raible C. C. and Strassmann, K. M., 79-88, Bern, Switzerland: OCCR, FOEN, MeteoSwiss, C2SM, Agroscope, ProClim, Bern, Switzerland, 2015.

Bullinger, J., Lämmli, M., and Leuzinger-Piccand, C.: Le site magdalénien de plein air de Moosbühl: nouveaux éléments de datation et essai d'interprétation des données spatiales, Jahrb. Schweiz. Ges. Ur- Frühgesch., 80, 7-26, 1997.

Clark, J. S., Merkt, J., and Müller, H.: Post-glacial fire, vegetation and human history on the northern alpine forelands, SouthWestern Germany, J. Ecol., 77, 897-925, 1989.

Clegg, B. F., Tinner, W., Gavin, D. G., and Hu, F. S.: Morphological differentiation of Betula (birch) pollen in northwest North America and its palaeoecological application, Holocene, 16, 791-803, https://doi.org/10.1191/0959683605hl788rp, 2005.

Colombaroli, D. and Tinner, W.: Determining the long-term changes in biodiversity and provisioning services along a transect from Central Europe to the Mediterranean, Holocene, 23, 1625-1634, https://doi.org/10.1177/0959683613496290, 2013.

Conedera, M., Krebs, P., Tinner, W., Pradella, M., and Torriani, D.: The cultivation of Castanea sativa (Mill.) in Europe, from its origin to its diffusion on a continentalscale, Veg. Hist. Archaeobot., 13, 161-179, https://doi.org/10.1007/s00334-004-0038-7, 2004.

Conedera, M., Tinner, W., Crameri, S., Torriani, D., and Herold, A.: Taxon-related pollen source areas for lake basins in the southern Alps: an empirical approach, Veg. Hist. Archaeobot., 15, 263 272, https://doi.org/10.1007/s00334-006-0056-8, 2006.

Cupillard, C., Magny, M., Bocherens, H., Bridault, A., Bégeot, C., Bichet, V., Bossuet, G., Drucker, D. G., Gauthier, E., Jouannic, G., Millet, L., Richard, H., Rius, D., Ruffaldi, P., and WalterSimonnet, A.-V.: Changes in ecosystems, climate and societies in the Jura Mountains between 40 and $8 \mathrm{ka}$ cal BP, Quaternary Int., 378, 40-72, https://doi.org/10.1016/j.quaint.2014.05.032, 2015. de Beaulieu, J.-L. and Reille, M.: A long Upper Pleistocene pollen record from Les Echets, near Lyon, France, Boreas, 13, 111-132, 1984.

de Beaulieu, J.-L. and Reille, M.: The last climatic cycle at La Grande Pile (Vosges, France). A new profile, Quaternary Sci. Rev., 11, 431-438, 1992.

Duprat-Oualid, F., Rius, D., Bégeot, C., Magny, M., Millet, L., Wulf, S., and Appelt, O.: Vegetation response to abrupt climate changes in Western Europe from 45 to $14.7 \mathrm{k}$ cal a BP: the Bergsee lacustrine record (Black Forest, Germany), J. Quat. Sci., 32, 1008-1021, https://doi.org/10.1002/jqs.2972, 2017.

Ebnöther, C. and Wyss, S.: Brenodor - Brenodurum im Brennpunkt: Fakten, Fragen und Perspektiven - Zu den Ergebnissen der Sondierungen von 2000 im Vicus Reichenbachwald (BernEngehalbinsel), Jahrb. Schweiz. Ges. Ur- Frühgesch., 87, 282296, 2004.

Ehlers, J. and Gibbard, P. L. (Eds.): Quaternary Glaciations - Extent and Chronology: Part I: Europe, Elsevier, Amsterdam, The Netherlands, 2004.

Ehlers, J., Gibbard, P. L., and Hughes, P. D. (Eds.): Quaternary Glaciations - Extent and Chronology: A Closer Look, Elsevier, Amsterdam, The Netherlands, 2011.

Finsinger, W. and Tinner, W.: Minimum count sums for charcoal concentration estimates in pollen slides: accuracy and potential errors, Holocene, 15, 293-297, https://doi.org/10.1191/0959683605hl808rr, 2005.

Finsinger, W., Tinner, W., van der Knaap, W. O., and Ammann, B.: The expansion of hazel (Corylus avellana L.) in the southern Alps: a key for understanding its early Holocene history in Europe?, Quaternary Sci. Rev., 25, 612-631, https://doi.org/10.1016/j.quascirev.2005.05.006, 2006.

Finsinger, W., Schwörer, C., Heiri, O., Morales-Molino, C., Ribolini, A., Giesecke, T., Haas, J. N., Kaltenrieder, P., Magyari, E. K., Ravazzi, C., Rubiales, J. M., and Tinner, W.: Fire on ice and frozen trees? Inappropriate radiocarbon dating lead to unrealistic reconstructions, New Phytol., 222, 657-662, https://doi.org/10.1111/nph.15354, 2019.

Firbas, F. (Ed.): Spät- und nacheiszeitliche Waldgeschichte Mitteleuropas nördlich der Alpen, Fischer, Jena, Germany, 1949.

Fleitmann, D., Cheng, H., Badertscher, S., Edwards, R. L., Mudelsee, M., Göktürk, O. M., Fankhauser, A., Pickering, R., Raible, C. C., Matter, A., Kramers, J., and Tüysüz, O.: Timing and climatic impact of Greenland interstadials recorded in stalagmites from northern Turkey, Geophys. Res. Lett., 36, L19707, https://doi.org/10.1029/2009GL040050, 2009.

Gill, J. L., McLauchlan, K. K., Skibbe, A. M., Goring, S., Zirbel, C. R., and Williams, J. W.: Linking abundances of the dung fungus Sporormiella to the density of bison: implications for assessing grazing by megaherbivores in palaeorecords, J. Ecol., 101, 11251136, https://doi.org/10.1111/1365-2745.12130, 2013.

Gobet, E., Tinner, W., Hubschmid, P., Jansen, I., Wehrli, M., Ammann, B., and Wick, L.: Influence of human impact and bedrock differences on the vegetational history of the Insubrian Southern Alps, Veg. Hist. Archaeobot, 9, 175-178, https://doi.org/10.1007/BF01299802, 2000.

Gubler, M., Henne, P. D., Schwörer, C., Boltshauser-Kaltenrieder, P., Lotter, A. F., Brönnimann, S., and Tinner, W.: Microclimatic gradients provide evidence for a glacial refugium for temperate 
trees in a sheltered hilly landscape of Northern Italy, J. Biogeogr., 45, 2564-2575, https://doi.org/10.1111/jbi.13426, 2018.

Guthruf, J., Zeh, M., and Guthruf-Seiler, K. (Eds.): Kleinseen im Kanton Bern, Haupt, Bern, Switzerland, 138-141, 1999.

Hadorn, P.: Vegetationsgeschichtliche Studie am Nordufer des Lac de Neuchâtel: Pollenanalytische Untersuchungen im Loclat, in der Bucht von Hauterive/Saint-Blaise und in den neolithischen Ufersiedlungen von Saint-Blaise/Bain des Dames, Ph.D. thesis, University of Bern, Switzerland, 112 pp., 1992.

Hafner, A., Harb, C., Amstutz, M., Francuz, J., and Moll-Dau, F.: Moosseedorf, Moossee Oststation, Strandbad - Strandbadneubau, Pfahlbauten und das älteste Boot der Schweiz, Jahrbuch des Archäologischen Dienstes des Kantons Bern, ArchBE 2012, 71-77, https://doi.org/10.5169/seals-726587, 2012.

Hajdas, I., Ivy, S. D., Beer, J., Bonani, G., Imboden, D., Lotter, A. F., Sturm, M., and Suter, M.: AMS radiocarbon dating and varve chronology of Lake Soppensee: 6000 to $12000{ }^{14} \mathrm{C}$ years BP, Clim. Dynam., 9, 107-116, https://doi.org/10.1007/BF00209748, 1993.

Harb, C. (Ed.): Moosseedorf, Moossee - Ein Überblick über 160 Jahre Pfahlbauforschung, Archäologischer Dienst des Kantons Bern, Bern, Switzerland, 2017.

Heegaard, E., Birks, H. J. B., and Telford, R. J.: Relationships between calibrated ages and depth in stratigraphical sequences: an estimation procedure by mixed-effect regression, Holocene, 15, 612-618, https://doi.org/10.1191/0959683605hl836rr, 2005.

Heiri, O. and Millet, L.: Reconstruction of late glacial summer temperatures from chironomid assemblages in Lac Lautrey (Jura, France), J. Quat. Sci., 20, 33-44, https://doi.org/10.1002/jqs.895, 2005.

Heiri, O., Brooks, S. J., Renssen, H., Bedford, A., Hazekamp, M., Ilyashuk, B., Jeffers, E. S., Lang, B., Kirilova, E., Kuiper, S., Millet, L., Samartin, S., Tóth, M., Verbruggen, F., Watson, J. E., van Ash, N., Lammertsma, E., Amon, L., Birks, H. H., Birks, H. J. B., Mortensen, M. F., Hoek, W. Z., Magyari, E., Sobrino, C. M., Seppä, H., Tinner, W., Tonkov, S., Veski, S., and Lotter, A. F.: Validation of climate model-inferred regional temperature change for late-glacial Europe, Nat. Commun., 5, 4914, https://doi.org/10.1038/ncomms5914, 2014.

Heiri, O., Ilyashuk, B., Millet, L., Samartin, S., and Lotter A. F.: Stacking of discontinuous regional palaeoclimate records: Chironomid-based summer temperatures from the Alpine region, Holocene, 25, 137-149, https://doi.org/10.1177/0959683614556382, 2015.

Henne, P. D., Elkin, C. M., Reineking, B., Bugmann, H., and Tinner, W.: Did soil development limit spruce (Picea abies) expansion in the Central Alps during the Holocene? Testing a palaeobotanical hypothesis with a dynamic landscape model, J. Biogeogr., 38, 933-949, https://doi.org/10.1111/j.1365-2699.2010.02460.x, 2011.

Henne, P. D., Elkin, C., Franke, J., Colombaroli, D., Calò, C., La Mantia, T., and Tinner, W.: Reviving extinct Mediterranean forests increases ecosystem potential in a warmer future, Front. Ecol. Environ., 13, 356-362, https://doi.org/10.1890/150027, 2015.

Henne, P. D., Bigalke, M., Büntgen, U., Colombaroli, D., Conedera, M., Feller, U., and Tinner, W.: An empirical perspective for understanding climate change impacts in Switzerland, Reg. Env- iron. Chang., 18, 205-221, https://doi.org/10.1007/s10113-0171182-9, 2018.

Hofer, P. and Meyer, H. J. (Eds.): Die Burg Nydegg: Forschungen zur frühen Geschichte von Bern, Haupt, Bern, 1991.

Hofstetter, S., Tinner, W., Valsecchi, V., Carraro, G., and Conedera, M.: Lateglacial and Holocene vegetation history in the Insubrian Southern Alps - New indications from a small-scale site, Veg. Hist. Archaeobot., 15, 87-98, https://doi.org/10.1007/s00334005-0005-y, 2006.

Hughes, P. D., Gibbard, P. L., and Ehlers, J.: Timing of glaciation during the last glacial cycle: evaluating the concept of a global 'Last Glacial Maximum' (LGM), Earth-Sci. Rev., 125, 171-198, https://doi.org/10.1016/j.earscirev.2013.07.003, 2013.

Hurlbert, S. H.: The nonconcept of species diversity: a critique and alternative parameters, Ecology, 52, 577-586, https://doi.org/10.2307/1934145, 1971.

Ilyashuk, B., Gobet, E., Heiri, O., Lotter, A. F., van Leeuwen, J. F. N., van der Knaap, W. O., Ilyashuk, E., Oberli, F., and Ammann, B.: Lateglacial environmental and climatic changes at the Maloja Pass, Central Swiss Alps, as recorded by chironomids and pollen, Quaternary Sci. Rev., 28, 1340-1353, https://doi.org/10.1016/j.quascirev.2009.01.007, 2009.

Joannin, S., Vannière, B., Galop, D., Peyron, O., Haas, J. N., Gilli, A., Chapron, E., Wirth, S. B., Anselmetti, F., Desmet, M., and Magny, M.: Climate and vegetation changes during the Lateglacial and early-middle Holocene at Lake Ledro (southern Alps, Italy), Clim. Past, 9, 913-933, https://doi.org/10.5194/cp9-913-2013, 2013.

Kaltenrieder, P., Belis, C. A., Hofstetter, S., Ammann, B., Ravazzi, C., and Tinner, W.: Environmental and climatic conditions at a potential Glacial refugial site of tree species near the Southern Alpine glaciers. New insights from multiproxy sedimentary studies at Lago della Costa (Euganean Hills, Northeastern Italy), Quaternary Sci. Rev., 28, 2647-2662, https://doi.org/10.1016/j.quascirev.2009.05.025, 2009.

Kleinmann, A., Merkt, J., and Müller, H.: Sedimente des Degersees: Ein Umweltarchiv - Sedimentologie und Palynologie, in: Pfahlbausiedlungen am Degersee - Archäologische und naturwissenschaftliche Untersuchungen, edited by: Mainberger, M., Merkt, J., and Kleinmann, A., Theiss, Darmstadt, Germany, 409471, 2015.

Kovats, R. S., Valentini, R., Bouwer, L. M., Georgopoulou, E., Jacob, D., Martin, E., and Soussana, J.-F.: Europe, in: Climate change 2014 - Impacts, adaptation, and vulnerability. Part B: Regional aspects. Contribution of Working Group II to the Fifth Assessment Report of the Intergovernmental Panel on Climate Change, edited by: Barros, V. R., Field, C. B., Dokken, D. J., Mastrandrea, M. D., Mach, K. J., Bilir, T. E., and White, L. L., 1267-1326, Cambridge University Press, Cambridge/ New York, UK/ USA, 2014.

Lang, G. (Ed.): Quartäre Vegetationsgeschichte Europas: Methoden und Ergebnisse, Fischer, Jena, Germany, 1994.

Larocque, I. and Finsinger, W.: Late-glacial chironomidbased temperature reconstructions for Lago Piccolo di Avigliana in the southwestern Alps (Italy), Palaeogeogr. Palaeoclimatol. Palaeoecol., 257, 207-223, https://doi.org/10.1016/j.palaeo.2007.10.021, 2008.

Lauber, K., Wagner, G., and Gygax, A. (Eds.): Flora helvetica, 5th edition, Haupt, Bern, Switzerland, 2014. 
Lauterbach, S., Chapron, E., Brauer, A., Hüls, M., Gilli, A., Arnaud, F., Piccin, A., Nomade, J., Desmet, M., von Grafenstein, U., and DecLakes Participants: A sedimentary record of Holocene surface runoff events and earthquake activity from Lake Iseo (Southern Alps, Italy), Holocene, 22, 749-760, https://doi.org/10.1177/0959683611430340, 2012.

Lister, G. S.: A 15,000-year isotopic record from Lake Zürich of deglaciation and climatic change in Switzerland, Quaternary Res., 29, 129-141, https://doi.org/10.1016/00335894(88)90056-7, 1988

Litt, T., Schölzel, C., Kühl, N., and Brauer, A.: Vegetation and climate history in the Westeifel Volcanic Field (Germany) during the past 11000 years based on annually laminated lacustrine maar sediments, Boreas, 38, 679-690, https://doi.org/10.1111/j.15023885.2009.00096.x, 2009.

Livingstone, D. M. and Lotter, A.F.: The relationship between air and water temperatures in lakes of the Swiss Plateau: a case study with palæolimnological implications, J. Paleolimnol., 19, 181198, https://doi.org/10.1023/A:1007904817619, 1998.

Lotter, A. F.: Late-glacial and Holocene vegetation history and dynamics as shown by pollen and plant macrofossil analyses in annually laminated sediments from Soppensee, central Switzerland, Veg. Hist. Archaeobot., 8, 165-184, https://doi.org/10.1007/BF02342718, 1999.

Lotter, A. F. and Kienast, F.: Validation of a forest succession model by means of annually laminated sediments, Geol. Surv. Finland, 14, 25-31, 1992.

Lotter, A. F. and Zbinden, H.: Late-Glacial pollen analysis, oxygen-isotope record, and radiocarbon stratigraphy from Rotsee (Lucerne), Central Swiss Plateau, Eclogae Geol. Helv., 82, 191-202, 1989.

Lotter, A. F., Birks, H. J. B., Eicher, U., Hofmann, W., Schwander, J., and Wick, L.: Younger Dryas and Allerød summer temperatures at Gerzensee (Switzerland) inferred from fossil pollen and cladoceran assemblages, Palaeogeogr. Palaeoclimatol. Palaeoecol., 159, 349-361, https://doi.org/10.1016/S00310182(00)00093-6, 2000.

Lotter, A. F., Heiri, O., Brooks, S., van Leeuwen, J. F. N., Eicher, U., and Ammann, B.: Rapid summer temperature changes during Termination 1a: high-resolution multi-proxy climate reconstructions from Gerzensee (Switzerland), Quaternary Sci. Rev., 36, 103-113, https://doi.org/10.1016/j.quascirev.2010.06.022, 2012.

Lourantou, A., Lavrič, J. V., Köhler, P., Barnola, J.-M., Paillard, D., Michel, E., Raynaud, D., and Chappellaz, J.: Constraint of the $\mathrm{CO}_{2}$ rise by new atmospheric carbon isotopic measurements during the last deglaciation, Global Biogeochem. Cy., 24, GB2015, https://doi.org/10.1029/2009GB003545, 2010.

Magny, M.: Orbital, ice-sheet, and possible solar forcing of Holocene lake-level fluctuations in west-central Europe: A comment on Bleicher, Holocene, 23, 1202-1212, https://doi.org/10.1177/0959683613483627, 2013.

Magny, M., Bossuet, G., Ruffaldi, P., Leroux, A., and Mouthon, J.: Orbital imprint on Holocene palaeohydrological variations in west-central Europe as reflected by lake-level changes at Cerin (Jura Mountains, eastern France), J. Quat. Sci., 26, 171-177, https://doi.org/10.1002/jqs.1436, 2011.

Magny, M., Joannin, S., Galop, D., Vannière, B., Haas, J. N., Bassetti, M., Bellintani, P., Scandolari, R., and Desmet, M.: Holocene palaeohydrological changes in the northern Mediter- ranean borderlands as reflected by the lake-level record of Lake Ledro, northeastern Italy, Quatrnary Res., 77, 382-396, https://doi.org/10.1016/j.yqres.2012.01.005, 2012.

Marta, S., Mattoccia, M., and Sbordoni, V.: Modelling landscape dynamics in a glacial refugium - or the spatial and temporal fluctuations of tree line altitudes, J. Biogeogr., 40, 1767-1779, https://doi.org/10.1111/jbi.12120, 2013.

MeteoSwiss: Klimadiagramme und Normwerte pro Station, Federal Office of Meteorology and Climatology MeteoSwiss, ZurichAirport, Switzerland, 2017.

Monegato, G., Ravazzi, C., Donegana, M., Pini, R., Calderoni, G., and Wick, L.: Evidence of a two-fold glacial advance during the last glacial maximum in the Tagliamento end moraine system (eastern Alps), Quaternary Res., 68, 284-302, https://doi.org/10.1016/j.yqres.2007.07.002, 2007.

Moore, P. D., Webb, J. A., and Collison, M. E. (Eds.): Pollen Analysis, Blackwell Scientific Publications, Oxford, UK, 1991.

Nielsen, E.: Response of the Lateglacial fauna to climatic change, Palaeogeogr. Palaeoclimatol. Palaeoecol., 391, 99-110, https://doi.org/10.1016/j.palaeo.2012.12.012, 2013.

Nielsen, E. (Ed.): Die späteiszeitliche Fundstelle Moosseedorf, Moosbühl 1, Archäologischer Dienst des Kantons Bern, Bern, Switzerland, 2018.

North Greenland Ice Core Project members: High resolution record of Northern Hemisphere climate extending into the last interglacial period, Nature, 431, 147-151, https://doi.org/10.1038/nature02805, 2004.

Odgaard, B. V.: Fossil pollen as a record of past biodiversity, J. Biogeogr., 26, 7-17, https://doi.org/10.1046/j.13652699.1999.00280.x, 1999.

Pearson, R. G., Phillips, S. J., Loranty, M. M., Beck, P. S. A., Damoulas, T., Knight, S. J., and Goetz, S. J.: Shifts in Arctic vegetation and associated feedbacks under climate change, Nat. Clim. Chang., 3, 673-677, https://doi.org/10.1038/nclimate1858, 2013.

Pini, R.: A high-resolution Late-glacial-Holocene pollen diagram from Pian di Gembro (Central Alps, Northern Italy), Veget. Hist. Archaeobot., 11, 251-262, https://doi.org/10.1007/s003340200038, 2002.

Pini, R., Ravazzi, C., Aceti, A., Castellano, L., Perego, R., Quirino, T., and Vallè, F.: Ecological changes and human interaction in Valcamonica, the rock art valley, since the last deglaciation, Alpine Mediterr. Quat., 29, 19-34, 2016.

Ranalli, P. and Venturi, G.: Hemp as a raw material for industrial applications, Euphytica, 140, 1-6, https://doi.org/10.1007/s10681004-4749-8, 2004.

Ravazzi, C., Pini, R., Badino, F., De Amicis, M., Londeix, L., and Reimer, P. J.: The latest LGM culmination of the Garda Glacier (Italian Alps) and the onset of glacial termination. Age of glacial collapse and vegetation chronosequence, Quaternary Sci. Rev., 105, 26-47, https://doi.org/10.1016/j.quascirev.2014.09.014, 2014.

R Development Core Team: R: a language and environment for statistical computing. Vienna, Austria: R Foundation for Statistical Computing, Vienna, Austria, 2018.

Reille, M. (Ed.): Pollen et spores d'Europe et d'Afrique du Nord, Laboratoire de botanique historique et palynology, Marseille, France, 1992. 
Reimer, P. J., Bard, E., Bayliss, A., Beck, J. W., Blackwell, P. G., Bronk Ramsey, C., Buck, C. E., Cheng, H., Edwards, R. L., Friedrich, M., Grootes, P. M., Guilderson, T. P., Haflidason, H., Hajdas, I., Hatté, C., Heaton, T. J., Hoffmann, D. L., Hogg, A. G., Hughen, K. A., Kaiser, K. F., Kromer, B., Manning, S. W., Niu, M., Reimer, R. W., Richards, D. A., Scott, E. M., Southon, J. R., Staff, R. A., Turney, C. S. M., and van der Plicht, J.: IntCal13 and Marine13 radiocarbon age calibration curves 0-50,000 years cal BP, Radiocarbon, 55, 1869-1887, https://doi.org/10.2458/azu_js_rc.55.16947, 2013.

Rey, F., Schwörer, C., Gobet, E., Colombaroli, D., van Leeuwen, J. F. N., Schleiss, S., and Tinner, W.: Climatic and human impacts on mountain vegetation at Lauenensee (Bernese Alps, Switzerland) during the last 14,000 years, Holocene, 23, 1415-1427, https://doi.org/10.1177/0959683613489585, 2013.

Rey, F., Gobet, E., van Leeuwen, J. F. N., Gilli, A., van Raden, U. J., Hafner, A., Wey, O., Rhiner, J., Schmocker, D., Zünd, J., and Tinner, W.: Vegetational and agricultural dynamics at Burgäschisee (Swiss Plateau) recorded for 18,700 years by multi-proxy evidence from partly varved sediments, Veg. Hist. Archaeobot., 26, 571-586, https://doi.org/10.1007/s00334-017-0635-x, 2017.

Rey, F., Gobet, E., Schwörer, C., Wey, O., Hafner, A., and Tinner, W.: Causes and mechanisms of synchronous succession trajectories in primeval Central European mixed Fagus sylvatica forests, J. Ecol., 107, 1392-1408, https://doi.org/10.1111/13652745.13121, 2019a.

Rey, F., Gobet, E., Szidat, S., Lotter, A. F., Gilli, A., Hafner, A., and Tinner, W.: Radiocarbon wiggle matching on laminated sediments delivers high-precision chronologies, Radiocarbon, 61, 265-285, https://doi.org/10.1017/rdc.2018.47, 2019b.

Rey, F., Gobet, E., Schwörer, C., Hafner, A., Szidat, S., and Tinner, W.: Climate impacts on vegetation and fire dynamics since the Last Glacial Maximum at Moossee (Switzerland) - pollen dataset, Neotoma Palaeoecology Database, https://doi.org/10.21233/6N58-K786, 2020a.

Rey, F., Gobet, E., Schwörer, C., Hafner, A., Szidat, S., and Tinner, W.: Climate impacts on vegetation and fire dynamics since the Last Glacial Maximum at Moossee (Switzerland) - microscopic charcoal dataset, Neotoma Palaeoecology Database, https://doi.org/10.21233/XD5R-PF83, 2020b.

Samartin, S., Heiri, O., Lotter, A. F., and Tinner, W.: Climate warming and vegetation response after Heinrich event 1 (16 700-16 000 cal yr BP) in Europe south of the Alps, Clim. Past, 8, 19131927, https://doi.org/10.5194/cp-8-1913-2012, 2012.

Samartin, S., Heiri, O., Kaltenrieder, P., Kühl, N., and Tinner, W.: Reconstruction of full glacial environments and summer temperatures from Lago della Costa, a refugial site in Northern Italy, Quaternary Sci. Rev., 143, 107-119, https://doi.org/10.1016/j.quascirev.2016.04.005, 2016.

Schmid, S. M., Fügenschuh, B., Kissling, E., and Schuster, R.: Tectonic map and overall architecture of the Alpine orogeny, Eclogae Geol. Helv., 97, 93-117, https://doi.org/10.1007/s00015004-1113-x, 2004.

Schumacher, S. and Bugmann, H.: The relative importance of climatic effects, wildfires and management for future forest landscape dynamics in the Swiss Alps, Global Change Biol., 12, 1435-1450, https://doi.org/10.1111/j.1365-2486.2006.01188.x, 2006.
Schwander, J., Eicher, U., and Ammann, B.: Oxygen isotopes of lake marl at Gerzensee and Leysin (Switzerland), covering the Younger Dryas and two minor oscillations, and their correlation to the GRIP ice core, Palaeogeogr., Palaeoclimatol., Palaeoecol., 159, 203-214, https://doi.org/10.1016/S0031-0182(00)00085-7, 2000.

Schwörer, C., Henne, P. D., and Tinner, W.: A modeldata comparison of Holocene timberline changes in the Swiss Alps reveals past and future drivers of mountain forest dynamics, Global Change Biol., 20, 1512-1526, https://doi.org/10.1111/gcb.12456, 2014.

Schwörer, C., Colombaroli, D., Kaltenrieder, P., Rey, F., and Tinner, W.: Early human impact (5,000-3,000 BC) affects mountain forest dynamics in the Alps, J. Ecol., 103, 281-295, https://doi.org/10.1111/1365-2745.12354, 2015.

Seguinot, J., Ivy-Ochs, S., Jouvet, G., Huss, M., Funk, M., and Preusser, F.: Modelling last glacial cycle ice dynamics in the Alps, The Cryosphere, 12, 3265-3285, https://doi.org/10.5194/tc-12-3265-2018, 2018.

Šmilauer, P. and Lepš, J. (Eds.) Multivariate Analysis of Ecological Data using CANOCO 5, Cambridge University Press, Cambridge, UK, https://doi.org/10.1017/CBO9781139627061, 2014.

Stanford, J. D., Rohling, E. J., Bacon, S., Roberts, A. P., Grousset, F. E., and Bolshaw, M.: A new concept for the paleoceanographic evolution of Heinrich event 1 in the North Atlantic, Quaternary Sci. Rev., 30, 1047-1066, https://doi.org/10.1016/j.quascirev.2011.02.003, 2011.

Steinhilber, F., Beer, J., and Fröhlich, C.: Total solar irradiance during the Holocene, Geophys. Res. Lett., 36, L19704, https://doi.org/10.1029/2009GL040142, 2009.

Stockmarr, J.: Tablets with spores used in absolute pollen analysis, Pollen Spores, 13, 615-621, 1971.

Stuiver, M. and Polach, H. A.: Discussion - Reporting of ${ }^{14} \mathrm{C}$ data, Radiocarbon, 19, 355-363, https://doi.org/10.1017/S0033822200003672, 1977.

Stuiver, M. and Reimer, P.: Extended ${ }^{14} \mathrm{C}$ data base and revised CALIB 3.0 ${ }^{14} \mathrm{C}$ age calibration program, Radiocarbon, 35, 215230, https://doi.org/10.1017/S0033822200013904, 1993.

Szidat, S., Salazar, G. A., Vogel, E., Battaglia, M., Wacker, L., Synal, H.-A., and Türler, A.: ${ }^{14} \mathrm{C}$ analysis and sample preparation at the new Bern Laboratory for the Analysis of Radiocarbon with AMS (LARA), Radiocarbon, 56, 561-566, https://doi.org/10.2458/56.17457, 2014.

Ter Braak, C. J. F. and Prentice, I. C.: A theory of gradient analysis, Adv. Ecol. Res., 18, 271-317, https://doi.org/10.1016/S00652504(03)34003-6, 1998.

Tinner, W. and Hu, F. S.: Size parameters, size-class distribution and area number relationship of microscopic charcoal: Relevance for fire reconstruction, Holocene, 13, 499-505, https://doi.org/10.1191/0959683603hl615rp, 2003.

Tinner, W. and Kaltenrieder, P.: Rapid responses of high-mountain vegetation to early Holocene environmental changes in the Swiss Alps, J. Ecol., 93, 936-947, https://doi.org/10.1111/j.13652745.2005.01023.x, 2005.

Tinner, W. and Lotter, A. F.: Central European vegetation response to abrupt climate change at $8.2 \mathrm{ka}$, Geology, 29, 551-554, https://doi.org/10.1130/00917613(2001)029<0551:CEVRTA>2.0.CO;2, 2001. 
Tinner, W. and Lotter, A. F.: Holocene expansions of Fagus silvatica and Abies alba in Central Europe: where are we after eight decades of debate?, Quaternary Sci. Rev., 25, 526-549, https://doi.org/10.1016/j.quascirev.2005.03.017, 2006.

Tinner, W. and Vescovi, E.: Ecologia e oscillazioni del limite degli alberi nelle Alpi dal Pleniglaciale al presente, Acta Geol., 82, $7-15,2007$.

Tinner, W., Conedera, M., Ammann, B., Gaggeler, H. W., Gedye, S., Jones, R., and Sagesser, B.: Pollen and charcoal in lake sediments compared with historically documented forest fires in southern Switzerland since AD 1920, Holocene, 8, 31-42, https://doi.org/10.1191/095968398667205430, 1998.

Tinner, W., Hubschmid, P., Wehrli, M., Ammann, B., and Conedera, M.: Long-term forest fire ecology and dynamics in southern Switzerland, J. Ecol., 87, 273-289, https://doi.org/10.1046/j.1365-2745.1999.00346.x, 1999.

Tinner, W., Lotter, A. F., Ammann, B., Conedera, M., Hubschmid, P., van Leeuwen, J. F. N., and Wehrli, M.: Climatic change and contemporaneous land-use phases north and south of the Alps $2300 \mathrm{BC}$ to $800 \mathrm{AD}$, Quaternary Sci. Rev., 22, 1447-1460, https://doi.org/10.1016/S0277-3791(03)00083-0, 2003.

Tinner, W., Conedera, M., Ammann, B., and Lotter, A. F.: Fire ecology north and south of the Alps since the last ice age, Holocene, 15, 1214-1226, https://doi.org/10.1191/0959683605hl892rp, 2005.

Tinner, W., Colombaroli, D., Heiri, O., Henne, P. D., Steinacher, M., Untenecker, J., Vescovi, E., Allen, J. R. M., Carraro, G., Conedera, M., Joos, F., Lotter, A. F., Luterbacher, J., Samartin, S., and Valsecchi, V.: The past ecology of Abies alba provides new perspectives on future responses of silver fir forests to global warming, Ecol. Monogr., 83, 419-439, https://doi.org/10.1890/122231.1, 2013.

Uglietti, C., Zapf, A., Jenk, T. M., Sigl, M., Szidat, S., Salazar, G., and Schwikowski, M.: Radiocarbon dating of glacier ice: overview, optimisation, validation and potential, The Cryosphere, 10, 3091-3105, https://doi.org/10.5194/tc-10-30912016, 2016.

van der Knaap, W. O.: Estimating pollen diversity from pollen accumulation rates: a method to assess taxonomic richness in the landscape, Holocene, 19, 159-163, https://doi.org/10.1177/0959683608098962, 2009.

van Geel, B.: Fossil ascomycetes in Quaternary deposits, Nova Hedwigia, 82, 313-329, https://doi.org/10.1127/00295035/2006/0082-0313, 2006.

van Geel, B., Buurman, J., Brinkkemper, O., Schelvis, J., Aptroot, A., van Reenen, G., and Hakbijl, T.: Environmental reconstruction of a Roman Period settlement site in Uitgeest (The Netherlands), with special reference to coprophilous fungi, J. Archaeol. Sci., 30, 873-883, https://doi.org/10.1016/S03054403(02)00265-0, 2003

van Raden, U. J., Colombaroli, D., Gilli, A., Schwander, J., Bernasconi, S. M., van Leeuwen, J., Leuenberger, M., and Eicher, U.: High-resolution late-glacial chronology for the Gerzensee lake record (Switzerland): $\delta^{18} \mathrm{O}$ correlation between a Gerzensee-stack and NGRIP, Palaeogeogr. Palaeoclimatol. Palaeoecol., 391, 13-24, https://doi.org/10.1016/j.palaeo.2012.05.017, 2013.
Vescovi, E., Ravazzi, C., Arpenti, E., Finsinger, W., Pini, R., Valsecchi, V., Wick, L., Ammann, B., and Tinner, W.: Interactions between climate and vegetation during the Lateglacial period as recorded by lake and mire sediment archives in Northern Italy and Southern Switzerland, Quaternary Sci. Rev., 26, 1650-1669, https://doi.org/10.1016/j.quascirev.2007.03.005, 2007.

von Büren, G. (Ed.): Der Moosseedorfsee - Neue Beiträge zur Kenntnis seiner Physiographie und Biologie mit Einbezug des Kleinen Moosseedorfsees (Hofwilsee), Haupt, Bern, Switzerland, 1943.

von Grafenstein, U., Erlenkeuser, H., Müller, J., Jouzel, J., and Johnsen, S.: The cold event 8200 years ago documented in oxygen isotope records of precipitation in Europe and Greenland, Clim. Dynam., 14, 73-81, https://doi.org/10.1007/s003820050210, 1998.

von Grafenstein, U., Erlenkeuser, H., Brauer, A., Jouzel, J., and Johnsen, S. J.: A mid- European decadal isotope-climate record from 15,500 to 5000 years BP, Science, 284, 1654-1657, https://doi.org/10.1126/science.284.5420.1654, 1999.

von Grafenstein, U., Eicher, U., Erlenkeuser, H., Ruch, P., Schwander, J., and Ammann, B.: Isotope signature of the Younger Dryas and two minor oscillations at Gerzensee (Switzerland): palaeoclimatic and palaeolimnologic interpretation based on bulk and biogenic carbonates, Palaeogeogr., Palaeoclimatol., Palaeoecol., 159, 215-229, https://doi.org/10.1016/S0031-0182(00)00086-9, 2000.

Wehrli, M., Tinner, W., and Ammann, B.: 16000 years of vegetation and settlement history from Egelsee (Menzingen, central Switzerland), Holocene, 17, 747-761, https://doi.org/10.1177/0959683607080515, 2007.

Welten, M. (Ed.): Vegetationsgeschichtliche Untersuchungen in den westlichen Schweizer Alpen: Bern-Wallis, Denkschr. Schweiz. Natforsch. Ges., 95, 1-104, 1982.

Wick, L.: Das Hinterland von Augusta Raurica: Paläoökologische Untersuchungen zur Vegetation und Landnutzung von der Eisenzeit bis zum Mittelalter, Jahresberichte aus Augst und Kaiseraugst, 36, 209-215, 2015.

Wick, L. and Möhl, A.: The mid-Holocene extinction of silver fir (Abies alba) in the Southern Alps: a consequence of forest fires? Palaeobotanical records and forest simulations, Veg. Hist. Archaeobot., 15, 435-444, https://doi.org/10.1007/s00334-0060051-0, 2006.

Willis, K. J. and Birks, H. J. B.: What is natural? The need for a long-term perspective in biodiversity conservation, Science, 314, 1261-1265, https://doi.org/10.1126/science.1122667, 2006.

Wirsig, C., Zasadni, J., Christl, M., Akçar, N., and IvyOchs, S.: Dating the onset of LGM ice surface lowering in the High Alps, Quaternary Sci. Rev., 143, 37-50, https://doi.org/10.1016/j.quascirev.2016.05.001, 2016.

Wirtz, K. W. and Lemmen, C.: A global dynamic model for the Neolithic transition, Clim. Chang., 59, 333-367, https://doi.org/10.1023/A:1024858532005, 2003.

Woillard, G. M.: Grande Pile peat bog: a continuous pollen record for the last 140,000 years, Quaternary Res., 9, 1-21, 1978. 